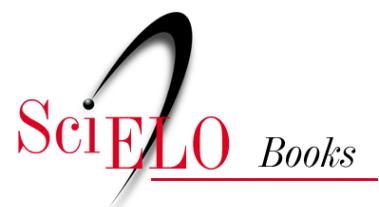

\title{
O massacre de Manguinhos
}

\author{
Herman Lent
}

LENT, H. O massacre de Manguinhos [online]. 2nd ed. Rio de Janeiro: Editora FIOCRUZ: Edições Livres, 2019, 112 p, Memória viva collection. ISBN: 978-85-7541-640-2. https://doi.org/10.7476/9788575416402.

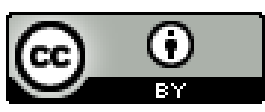

All the contents of this work, except where otherwise noted, is licensed under a Creative Commons Attribution 4.0 International license.

Todo o conteúdo deste trabalho, exceto quando houver ressalva, é publicado sob a licença Creative Commons Atribição 4.0. 
Coleção Memória Viva

corae

○

massacre

de

manguinhos

Herman Lent 
0

3) massacre

de

manguinhos

Herman Lent 


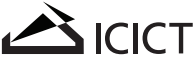

Instituto de Comunicaçăo e Informaçăo

\section{IOC}

Instituto Oswaldo Cruz

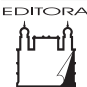

FIOCRUZ

\section{Fundação Oswaldo Cruz}

Presidente

Nísia Trindade Lima

Vice-presidente de Ambiente, Atenção e Promoção da Saúde Marco Antonio Carneiro Menezes

Vice-presidente de Ensino, Informação e Comunicação Cristiani Vieira Machado

Vice-presidente de Gestão e Desenvolvimento Institucional Mario Santos Moreira

Vice-presidente de Pesquisa e Coleções Científicas Rodrigo Correa de Oliveira

Vice-presidente de Produção e Inovação em Saúde Marco Aurelio Krieger

\section{Instituto de Comunicação e Informação Científica e Tecnológica em Saúde}

Diretor

Rodrigo Murtinho

Vice-diretor de Pesquisa, Ensino e Desenvolvimento Tecnológico Christovam Barcellos

Vice-diretor de Informação e Comunicação

Tânia Cristina Pereira dos Santos

Vice-diretor de Desenvolvimento Institucional

Jacques Sochaczewski

\section{Casa de Oswaldo Cruz}

Diretor

Paulo Roberto Elian dos Santos

Vice-Diretora de Gestão e Desenvolvimento Institucional Nercilene Santos da Silva Monteiro

Vice-Diretor de Patrimônio Cultural e Divulgação Científica Marcos José de Araújo Pinheiro

Vice-Diretora de Pesquisa e Educação

Magali Romero Sá

\section{Instituto Oswaldo Cruz}

Diretor

José Paulo Gagliardi Leite

Vice-diretor de Pesquisa, Desenvolvimento Tecnológico e Inovação Jonas Enrique Perales Aguilar

Vice-diretora de Laboratórios de Referência e Coleções Biológicas Elizabeth Ferreira Rangel

Vice-diretoria de Ensino, Informação e Comunicação Marcelo Alves Pinto

Vice-diretoria de Desenvolvimento Institucional e Gestão Wania Regina Tolentino Santiago

\section{Editora Fiocruz}

Diretora

Cristiani Vieira Machado

Editor Executivo

João Carlos Canossa Mendes

Editores Científicos

Carlos Machado de Freitas

Gilberto Hochman

Conselho Editorial

Denise Valle, José Roberto Lapa e Silva, Kenneth Rochel de Camargo Jr., Ligia Maria Vieira da Silva, Marcos Cueto, Maria Cecília de Souza Minayo, Marilia Santini de Oliveira, Moisés Goldbaum, Rafael Linden 


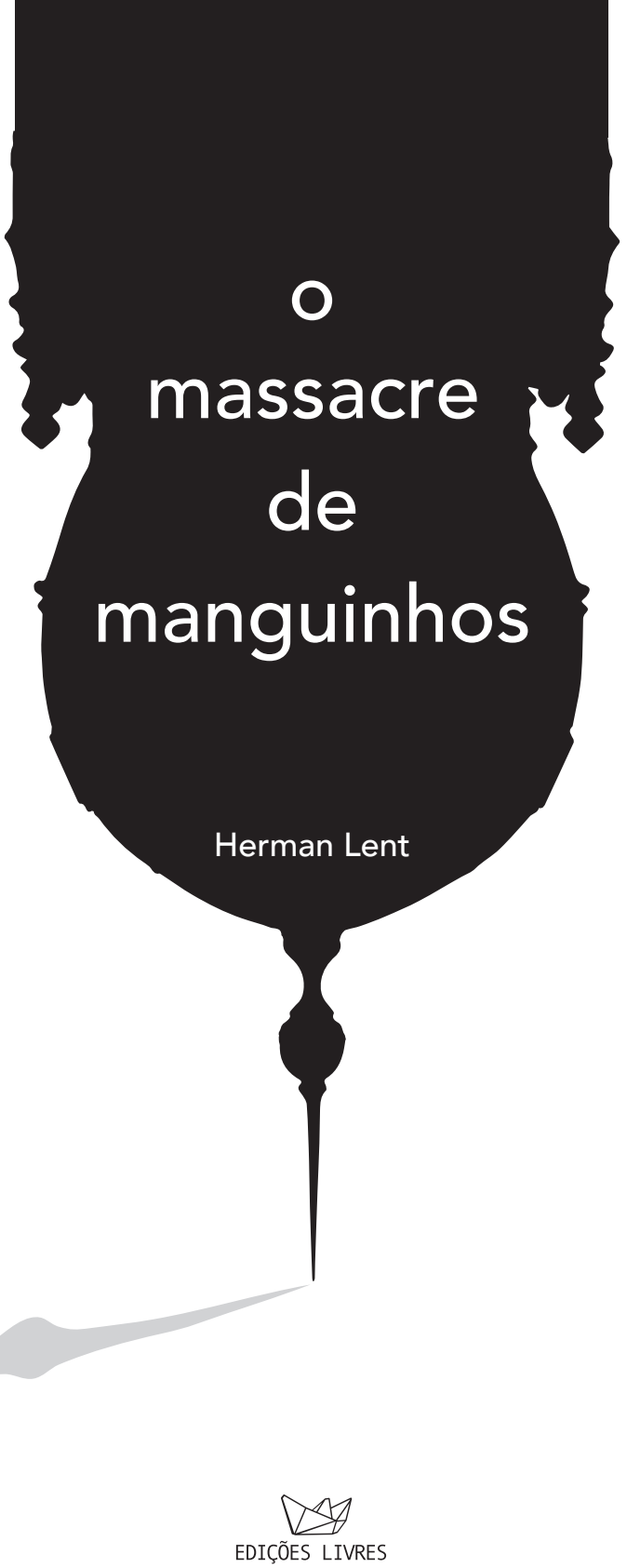

Rio de Janeiro

2019 
2a Edição: Edições Livres, 2019

\section{Coordenação Geral}

Rodrigo Murtinho

Coordenação Editorial

Mauro Campello

Mel Bonfim

Patrícia Ferreira

\section{Revisão}

Vinícius Renaud

Wanda Brant

Capa e Projeto Gráfico

Mauro Campello

Editoração Eletrônica

Multimeios | Icict | Fiocruz

Pesquisa Iconográfica

Francisco dos Santos Lourenço

Mauro Campello

Renato Cordeiro

\section{Fotografias}

Acervo Renato Cordeiro | IOC | Fiocruz

Acervo Casa de Oswaldo Cruz | COC | Fiocruz

Digitalização dos originais

Rodrigo Méxas

Este livro foi publicado de acordo com a Política de Acesso Aberto ao Conhecimento da Fiocruz. Os textos constantes nessa publicação podem ser copiados e compartilhados desde que: não sejam utilizados para fins comerciais; e, que seja citada a fonte e atribuídos os devidos créditos. Distribuição gratuita.

Ficha catalográfica elaborada pela Biblioteca de Manguinhos | ICICT | FIOCRUZ - RJ

L574 Lent, Herman

O massacre de Manguinhos / Herman Lent. - Rio de Janeiro : Fiocruz : Edições Livres, 2019.

112 p. : il.

\section{Coleção Memória Viva.}

A reedição deste livro, publicado originalmente em 1978 pela Avenir Editora, é resultado do projeto "Acesso aberto e uso da literatura científica no ensino", desenvolvido no ICICT, sob a coordenação de Rodrigo Murtinho.

1. Pesquisadores. 2. Perseguição. 3. Fundação Oswaldo Cruz. 4. Saúde pública. 5. Pesquisa científica e desenvolvimento tecnológico. I. Murtinho, Rodrigo. II. Título. III. Série. 


\title{
O projeto
}

\begin{abstract}
A nova edição de $O$ Massacre de Manguinhos inaugura a Coleção Memória Viva, criada para tornar acessíveis aos leitores obras de reconhecida relevância acadêmica e institucional. A coleção é fruto do projeto "Acesso aberto e uso da literatura científica no ensino", desenvolvido no Instituto de Comunicação e Informação Científica e Tecnológica em Saúde (Icict), da Fundação Oswaldo Cruz (Fiocruz), onde as políticas de acesso aberto têm sido encaradas como estratégicas para o fortalecimento da ciência e da saúde pública.
\end{abstract}

Entre as obras que estamos resgatando e reeditando há livros esgotados, indisponíveis nas livrarias físicas e virtuais, além de dissertações e teses acadêmicas que ainda não integram acervos online. Foram escolhidos a partir de pesquisa com alunos e professores do Programa de Pós-Graduação em Informação e Comunicação em Saúde (PPGICS), que mapeou títulos usados habitualmente nas atividades de ensino e as dificuldades em acessá-los.

A recuperação desses trabalhos tem como objetivo a preservação de saberes na interseção entre saúde coletiva, informação e comunicação. Busca contribuir para a ampliação da Política de Acesso Aberto e a constituição de políticas de Memória e de Ciência Aberta da Fiocruz. Além disso, colabora para o fortalecimento das políticas públicas de preservação da memória bibliográfica nacional.

O Massacre de Manguinhos também é o primeiro livro do selo Edições Livres. Como o próprio nome sugere, o selo tem a missão de lançar publicações com livre circulação na internet, tornando disponíveis todas as obras recuperadas pelo projeto. Assim, a narrativa do pesquisador Herman Lent sobre a repressão da ditadura militar à atividade científica poderá ser lida em seu formato digital, na íntegra e de forma gratuita. Mas, devido à sua importância histórica para a memória da ciência, da democracia e da Fiocruz, este livro está sendo lançado também no formato impresso. Casa de Oswaldo Cruz (COC), Instituto Oswaldo Cruz (IOC) e Editora Fiocruz são parceiros do Icict na iniciativa. 
Esta nova edição traz, além do texto memorável de Herman Lent, publicado originalmente em 1978, o prefácio de Nísia Trindade Lima, presidente da Fiocruz, que destaca a relação entre ciência e democracia; e os posfácios "Ciência, saúde e política no regime militar: O Massacre de Manguinhos", de Wanda Hamilton, pesquisadora da Casa de Oswaldo Cruz, e "Momentos sombrios para não serem esquecidos pelas novas gerações", escrito pelo pesquisador emérito da Fiocruz e titular do Instituto Oswaldo Cruz, Renato Cordeiro. Uma série de imagens históricas do Acervo da Casa de Oswaldo Cruz e do arquivo pessoal de Renato Cordeiro integram o volume, valorizando ainda mais o caráter precioso desse testemunho, em sua missão de, narrando fatos, combater o esquecimento.

O projeto foi financiado pelo do Programa de Apoio à Pesquisa Estratégica em Saúde - PAPES VII/Jovem Cientista (Fiocruz/CNPq), e pelo Programa de Indução à Pesquisa e Desenvolvimento Tecnológico - PIPDT (Icict/Fiocruz).

\section{Rodrigo Murtinho e Mauro Campello} Coordenadores do projeto

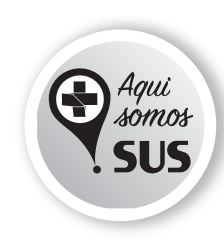

REALIZAÇ̃̃o
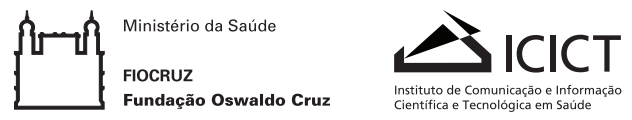

PARCEIROS NESTA EDIÇÃO

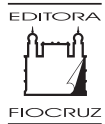


Projeto Acesso Aberto e uso da literatura científica no ensino

Equipe do projeto:

Rodrigo Murtinho | coordenador Mauro Campello | coordenador adjunto Anne Ferreira dos Santos Cristina Maria Rabelais Duarte Fátima Duarte Ilma Noronha Leonardo Simonini Luciana Danielli Marilene Santos Mel Bonfim Mônica Garcia Patrícia Castro Ferreira

Este projeto tem o apoio do Programa de Apoio à Pesquisa Estratégica em Saúde - PAPES VII/Jovem Cientista (Fiocruz/CNPq), e do Programa de Indução à Pesquisa e Desenvolvimento Tecnológico PIPDT (Icict/Fiocruz).

APOIO

\section{圆CNPq}




\section{Sumário}

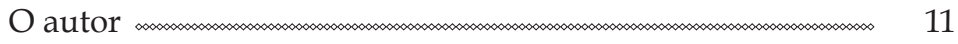

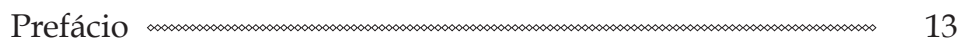

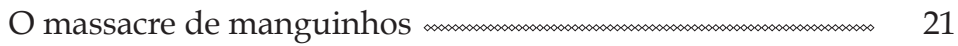

Posfácio - Ciência, saúde e política no regime milita:

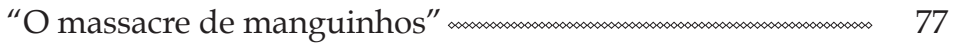

Posfácio - Momentos sombrios para não serem

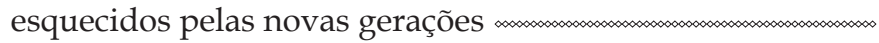




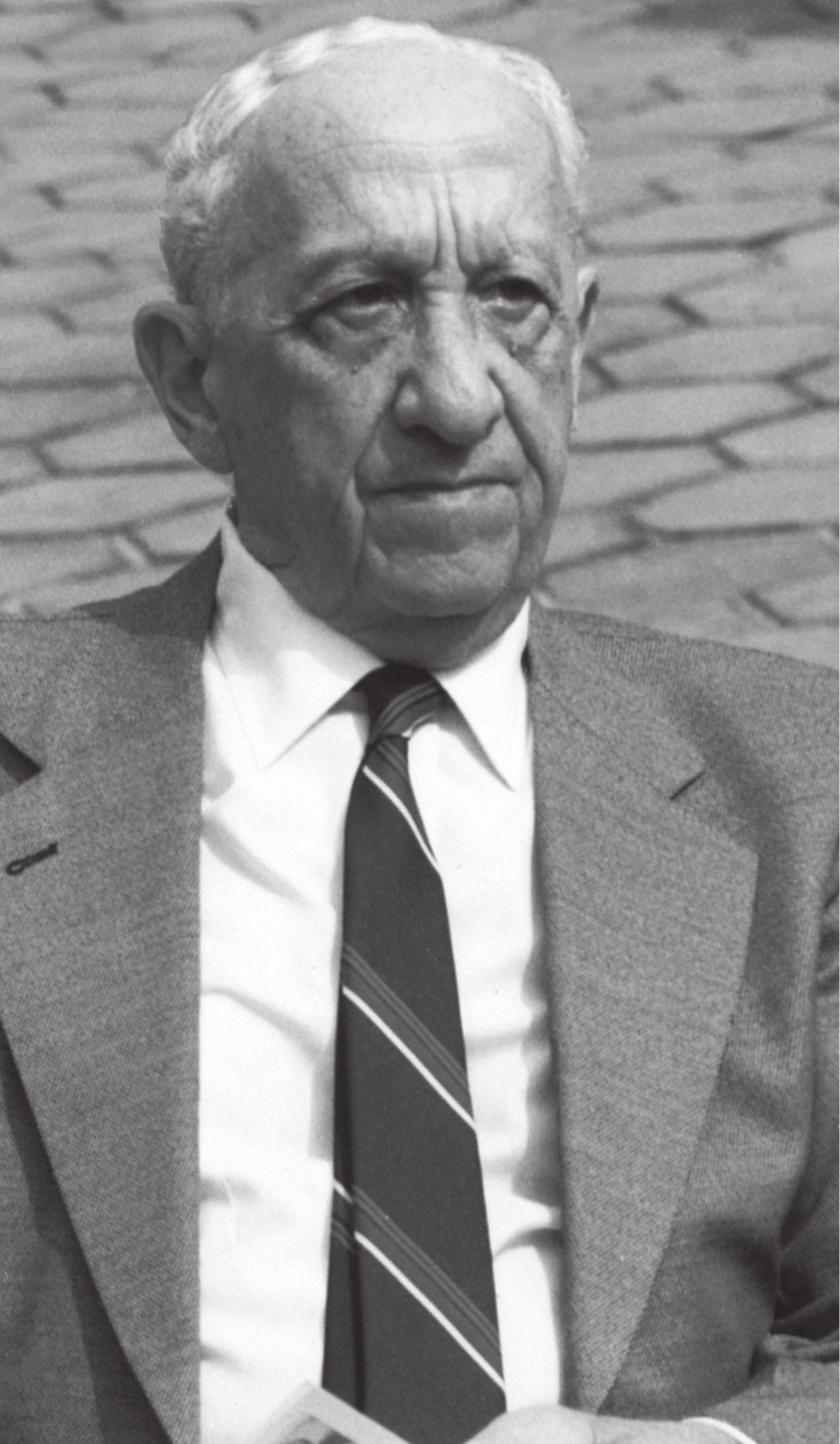


C arioca, Herman Lent nasceu em 1911. Aos 23 anos formou-se pela Faculdade Nacional de Medicina do Rio de Janeiro. Em 1933 era contratado para os quadros do Instituto como estagiário de Lauro Travassos. No Instituto Oswaldo Cruz trabalhou durante 49 anos, onde exerceu os cargos de pesquisador, professor, chefe da Secção de Entomologia. Entre 1961 e 1964 chefiou a Divisão de Zoologia. No início publicou vários trabalhos em helmintologia, mas posteriormente, por influências de Arthur Neiva, voltou-se para a entomologia, especializando-se em barbeiros. Foi Lent quem implantou, em 1935, em Manguinhos, a criação de barbeiros.

Herman Lent foi professor do Colégio Pedro II, da Universidade do Distrito Federal, da Escola de Medicina e Cirurgia, de cursos de Saúde Pública do Ministério da Saúde, professor conferencista do $\mathrm{CNPq}$, e da pós-graduação das universidades de Assunção, Bahia, Paraná e Rio de Janeiro, entre outros. Foi editor da "Revista Brasileira de Biologia" e das "Memórias do Instituto Oswaldo Cruz", membro do Conselho Editorial da "Revista Biotrópica" publicada nos Estados Unidos (1969-1975) e chefe da seção de história natural da grande "Enciclopédia Delta Larrousse" (1970).

Com a cassação política no Massacre de Manguinhos, Lent foi para a Universidade de Los Andes, em Mérida, Venezuela e foi pesquisador associado do Museu Americano de História Natural de Nova Iorque. Em 1950 recebeu diploma e medalha comemorativa pelos 50 anos do Instituto Oswaldo Cruz; medalha comemorativa pelo cinquentenário da descoberta da doença de Chagas (1959); medalha Pirajá da Silva comemorativa do cinquentenário da identificação do Schistosoma mansoni; em 1972, recebeu o prêmio Costa Lima de Entomologia, da Academia Brasileira de Ciências, entre vários outros. Ingressou na Universidade Santa Úrsula em 1976, onde foi decano do Centro de Ciências Biológicas.

Lent é fundador das sociedades Brasileiras de Zoologia, Microbiologia e da Brasileira para o Progresso da Ciência (SBPC); é membro da Sociedade Americana de Parasitologistas, das sociedades Chilenas de História Natural e de Entomologia, da Academia de Zoologia de Agra, na Índia, Federação LatinoAmericana de Parasitologia e da Association of Tropical Biology. 
Terceiro pavimento do Pavilhão

Mourisco, 1910.

Acerco Casa de Oswaldo Cruz.

Foto: J. Pinto.

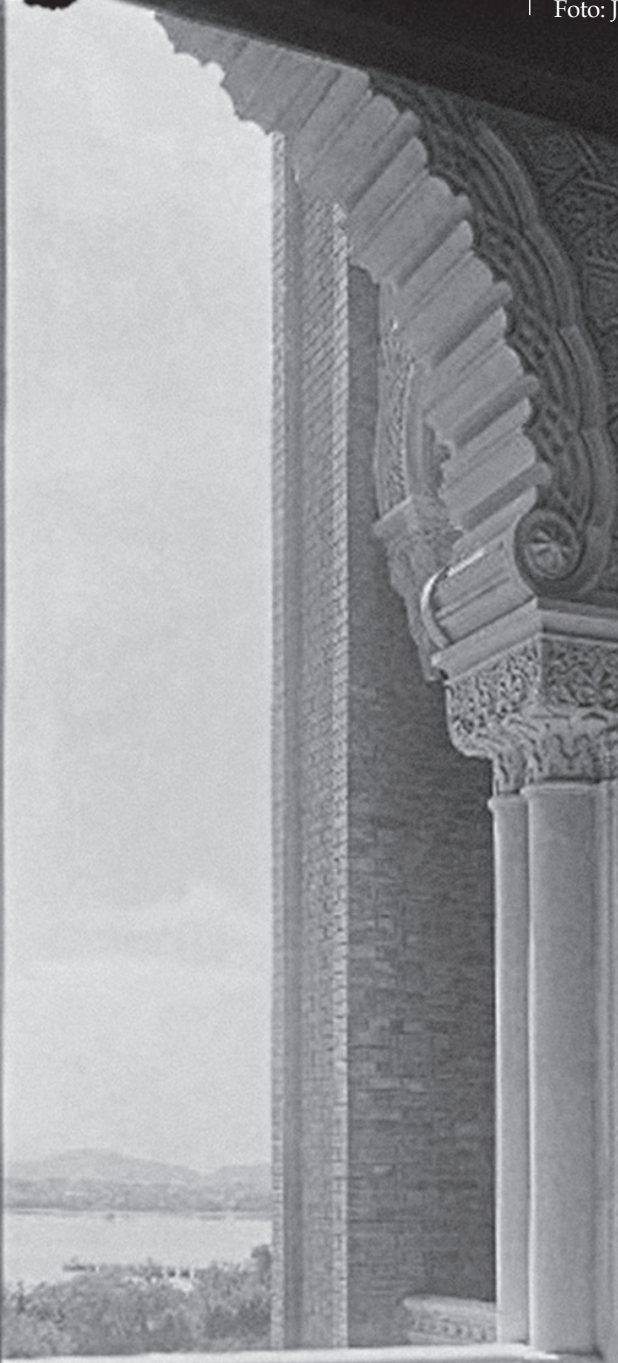

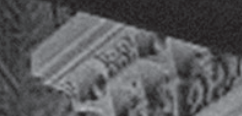
ह1 150 5 15. 186 (1) 8 .

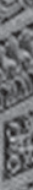
(3) - 40

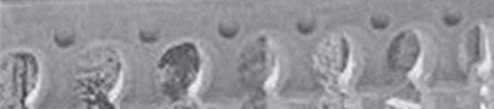
$32,19+200$

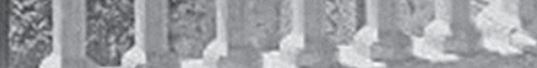

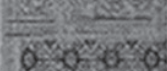

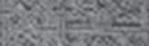

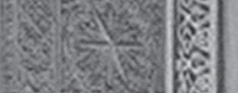

a.

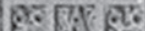

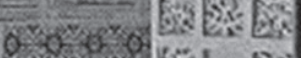

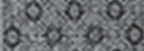
(0) $0 \%$ 8. $5.0 \%$ 651 Si 6 \& on 80 $0090 \%$ $20 \%$. s. condin 


\section{Prefácio}

Ciência e democracia: Prefácio à segunda edição de O Massacre de Manguinhos

reedição de O Massacre de Manguinhos merece
ser muito comemorada, pois se trata de tornar acessível ao leitor contemporâneo uma referência obrigatória para os estudos sobre o impacto da ditadura militar na atividade científica realizada no Brasil. Concebida originalmente como análise e testemunho registrados pelo conceituado entomologista Herman Lent que, junto com outros cientistas de sua geração, tiveram a história pessoal marcada pelo trágico evento, a obra pode ser lida agora como fonte que transcende o registro da memória, por si só, tão importante. É o que demonstram Renato Balão Cordeiro e Wanda Hamilton nos textos escritos para esta edição, ao enfatizarem a perda provocada pelas cassações para a atividade científica, a importância do não esquecimento e o impacto da reintegração dos cientistas na Fiocruz, em 1986, durante a gestão de 
Sérgio Arouca. Em síntese, somos convidados, em decorrência da oportuna iniciativa do Instituto de Comunicação e Informação Científica e Tecnológica em Saúde (Icict/Fiocruz), a problematizar as relações entre ciência e democracia, e a colocar em pauta as ilusões que, com frequência, promovem a separação entre ciência e política.

A forma ilusória de observar a atividade científica, reiterando sua autonomia diante de processos sociais mais amplos, foi bem analisada pelo sociólogo Robert Merton em texto clássico sobre as relações entre ciência e democracia. Merton aludiu ao contexto da Segunda Guerra Mundial para argumentar sobre o equívoco dos cientistas que acreditavam no caráter autônomo de sua atividade. Em sua crítica, observou o "isolamento otimista" dos que se viam como independentes da sociedade e imunes ao conflito das culturas (MERTON, 1968).

Tal interdependência revela-se com toda força no "Massacre de Manguinhos". Com seus direitos políticos cassados pelo Ato Institucional $\mathrm{n}^{\circ} 5$ (AI5), em $1^{\circ}$ de abril de 1970, e compulsoriamente aposentados dois dias depois, os cientistas do Instituto Oswaldo Cruz (IOC) foram duramente atingidos em suas carreiras e em suas vidas pessoais. 
Pode-se afirmar que este fato lamentável e com profundas consequências resultou do autoritarismo inscrito, simultaneamente, nos macroprocessos da ditadura militar e em um cotidiano no qual delações e perseguições por desavenças no ambiente de trabalho moldavam também o regime político, fato, aliás, inerente a todos os governos autoritários. A possibilidade de leis de exceção gerarem cotidianamente arbítrio ainda maior do que as razões alegadas para sua elaboração foi bem sintetizada por Pedro Aleixo, vice-presidente durante a presidência do marechal Costa e Silva, em seu argumento contrário ao AI-5: "Presidente, o problema de uma lei assim não é o senhor nem os que com o senhor governam o país; o problema é o guarda da esquina".

Desde abril de 1964, o então Instituto Oswaldo Cruz vivia sob a égide de intervenções e inquéritos militares, o primeiro deles sob a direção do general Aluizio Falcão, para apurar supostos atos de subversão e corrupção entre seus funcionários. Este e outros inquéritos que se seguiram nada provaram contra os cientistas de Manguinhos, mas o clima de hostilidade e repressão continuou, contando, a exemplo do que ocorreu em outras instituições, com 
aqueles que faziam o papel de "guardas da esquina". Antes do AI-5 e do episódio descrito neste livro, o cientista Walter Oswaldo Cruz, hematologista consagrado e líder de um dos mais modernos e conceituados laboratórios do IOC e do país, sofreu dura perseguição. Não obstante o reconhecimento internacional do valor de seu trabalho, o pesquisador, que morreu prematuramente em 1967, teve seu laboratório lacrado e o financiamento externo suspenso, fato descrito por Renato Cordeiro no texto que integra a presente edição e no qual a importância da atividade científica realizada na instituição durante o período de 1950 a 1970 é salientada.

As tensões internas em torno do perfil do Instituto Oswaldo Cruz, com a divisão entre os que defendiam o valor da pesquisa básica e os que tencionavam um modelo mais aplicado constituíram também outro fator importante no processo político institucional daqueles anos. Desde fins da década de 1950, um grupo de cientistas, entre eles os pesquisadores do Instituto Oswaldo Cruz Herman Lent, Haity Moussatché, Walter Oswaldo Cruz e Tito Cavalcanti, defendia a criação de um Ministério da Ciência e continuaram com esta mobilização nos anos que se seguiram ao golpe militar. É o que descreve Wanda 
Hamilton no texto elaborado para esta edição, ao contextualizar importantes aspectos do "Massacre de Manguinhos" e do modelo de gestão democrática, com eleição de presidentes, diretores de unidades e restauração do papel do conselho deliberativo, a partir da inovadora gestão de Sérgio Arouca.

Após 1968, várias universidades e institutos teriam professores e pesquisadores cassados ou aposentados por atos institucionais. Eram quase sempre descritos nos inquéritos como subversivos, e o fato, ainda insuficientemente estudado, de alguns terem participado do Partido Comunista, um atestado de que deveriam ser banidos junto com suas propostas vistas como indesejáveis para o país. Em Manguinhos, como em diferentes universidades e institutos de pesquisa, o mesmo ambiente de perseguição e destruição se impôs. A pesquisa histórica sobre os chamados anos de chumbo vem avançando desde a redemocratização e promulgação da Constituição de 1988, e há uma expressiva e qualificada bibliografia a respeito. Contudo, há muito o que se desvendar e analisar sobre o período, a exemplo do impacto do exílio de muitos cientistas e intelectuais e das dimensões subjetivas de todo esse processo. 
Por fim, vale lembrar que O Massacre de Manguinhos expressa muito bem o que o historiador Franco Venturi acentuou como força social das ideias, e que consiste, em poucas palavras, na capacidade criativa dos modos de se pensar e interpretar a vida social; as ideias não como reflexo, mas como fator dinâmico da sociedade (VENTURI, 2003). Impossível falar do trágico episódio da cassação do grupo dos dez cientistas do Instituto Oswaldo Cruz sem referência à ideia força do massacre. Que a obra possa ser lida, hoje, como um convite à preservação da memória dos cientistas vitimados pelo autoritarismo e também à defesa dos valores e da prática democrática para o desenvolvimento pleno da atividade científica e intelectual.

Nísia Trindade Lima

Presidente da Fiocruz

\section{Referências bibliográficas}

MERTON, Robert. Sociologia: teoria e VENTURI, Franco. Utopia e reforma no estrutura. São Paulo: Mestre Jou, 1968. Iluminismo. Bauru: Edusc, 2003. 


\title{
o massacre \\ de manguinhos
}

\author{
Yerman hent.
}

1ํ edição, 1978

capa

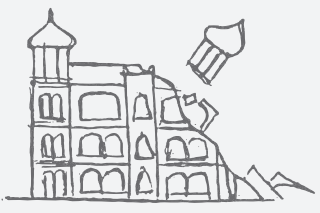

Oscar Niemeyer

produção gráfica

Sandra Mager

revisão

Damião Nascimento

volume 7

Coleção Depoimentos

Avenir Editora

Rio de Janeiro

avenir editora 


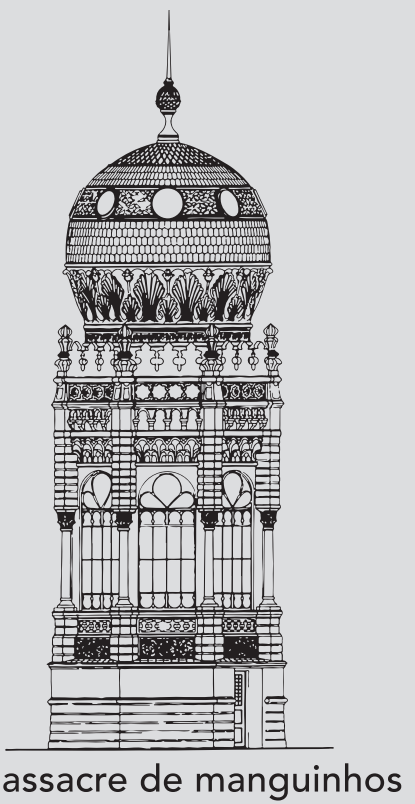




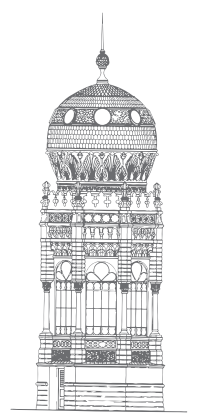

$\square$ ste depoimento pode ter aspectos veementes, mas $\amalg$ não pretende abrir polêmica. Ele se baseia em fatos e foi escrito a fim de deixar documentos sobre um período sombrio de nossa história, em que foram protagonistas pessoas pretensamente categorizadas relacionadas com a nossa - até anos atrás - maior instituição de pesquisa na área médico-biológica.

Era Manguinhos, nas suas origens, uma fazenda que o Barão de Pedro Afonso, no começo do século, adaptara para o preparo de soros e vacinas. Local afastado da cidade propriamente dita, era, então, somente acessível por via marítima. Aí, nesse lugar quase escondido, foi que se procurou plantar, ou quiçá enxertar, uma flor de difícil obtenção e delicada permanência. Não era flor nativa, era flor importada e se chamava pesquisa biológica. Praticamente inexistente na América Latina, foi trazida de seu lugar de origem - a velha Europa - por um homem que se caracterizou por amar, respeitar e utilizar as coisas mais novas, mais úteis, fundamentais. 
A Medicina Experimental nasceu em Paris com Claude Bernard e Louis Pasteur, no fim do século passado. O braço direito de Pasteur foi Emile Roux, o mesmo Roux que transmitiu a Oswaldo Cruz, de quem foi professor, a técnica e o espírito da pesquisa científica em sua especialidade, a Microbiologia. Alguns anos ali se passaram, até que o jovem médico regressasse ao seu país, onde o esperava um sucesso prático de retumbante e valiosa projeção.

Embora tenha realizado o grande e honesto serviço de utilidade imediata, qual o da extinção da febre amarela e o da implantação da vacinação antivariólica, certamente preocupou muito mais a Oswaldo Cruz a possibilidade que se lhe deparou de semear o conceito de pesquisa e investigação científicas, dilatando dessa maneira os horizontes restritos em que se agitavam os meios médicos nacionais. A carranca fechada, o traje escuro, a cartola, o diagnóstico dogmático, a quarentena, o horror à autópsia, sofreram então os primeiros embates. Os conceitos doutrinários apriorísticos, o vezo do magister, a erudição livresca, o autodidatismo, também sofreram as primeiras derrotas em nossa terra.

A pesquisa científica conquistava, assim, o seu núcleo inicial de irradiação. A tal ponto, que o primeiro Regimento do Instituto de Manguinhos, datado de 19 de março de 1908, atribuía ao Instituto 
as funções de uma verdadeira Universidade, na qual se entremeavam obrigações de pesquisa e de ensino, com deveres de preparo de soros, vacinas e produtos congêneres. E a orientação inicial compreendia o estudo da patologia do homem, dos animais e dos vegetais também, sucedendo esse espírito ao do antigo Instituto Soroterápico Federal, um simples laboratório de produção fundado para preparar soro e vacina contra o surto de peste bubônica nos portos brasileiros.

Mas Oswaldo Cruz também se notabilizou por ter fundado uma escola de pesquisadores científicos e, mais do que isso, de ter formado e reunido em torno de seu Instituto homens que fundaram outros Institutos, que descobriram doenças não descritas e mecanismos patológicos em diversos campos da Medicina Experimental, que estudaram e descobriram seres vivos até então desconhecidos para a ciência.

De Manguinhos se irradiaram, direta ou indiretamente, vários centros de investigação científica e de ensino, como o Instituto Biológico de São Paulo; o Instituto de Biofísica, no Rio de Janeiro; o Instituto Evandro Chagas, em Belém do Pará; vários laboratórios do Instituto Butantã, da Escola Paulista de Medicina e da Faculdade de Medicina de São Paulo e Ribeirão Preto; o Instituto Ezequiel 
Dias, de Belo Horizonte, e vários outros centros que se formaram ou se ampliaram pela difusão dos homens de Oswaldo Cruz, através do ensino e do exemplo dos laboratórios do Instituto matriz, que propiciavam modelo e fonte impulsionadora.

Na verdade, embora aumentassem numericamente os laboratórios em Manguinhos, minguavam ali os laboratórios produtivos, mas cresciam e se tornavam eficientes os que surgiam naquelas Escolas e nos Institutos que deles descendiam. Foi o Instituto de Manguinhos, no dizer de Walter Oswaldo Cruz, uma máquina de fazer máquina no desenvolvimento da nossa incipiente Biologia Experimental.

Infelizmente, este processo de deflagrar novas áreas não é facilmente compreendido pela maioria das pessoas, principalmente no momento em que o imediatismo, em grande parte derivado de educação deficiente em matéria científica, se apodera da orientação governamental. No caso, passam a ser de interesse médico, unicamente, os produtos de aplicação direta: o remédio, a vacina, o soro. Acham desperdício de tempo e de ingredientes que um cozinheiro se especialize em inventar novas iguarias ou melhorar as já conhecidas. Essas pessoas estão interessadas no alimento quotidiano, no ar que respiram, na vida de todos os dias. Nunca aprenderam que uma das coisas mais características da evolução social tem sido permitir, a parte da 
população, se ocupar de tarefas não imediatistas, tarefas que projetaram o homem, no tempo e no espaço, a resultados nunca anteriormente sonhados ou sequer ousados em imaginação.

Transformar o Instituto de investigação básica, uma verdadeira Universidade, tal a multiplicidade de objetivos que Oswaldo Cruz incluíra em seu primeiro regulamento, num Instituto de Higiene estrito com ênfase em produtos terapêuticos é como se contratar, usando imagem culinária, um cozinheiro francês, oriundo de várias gerações de cozinheiros sempre franceses, para preparar o rancho de um batalhão de recrutas. Não se minimize a significação dos produtos terapêuticos, que alguém precisa elaborar, mas não se desloque um lugar em que se plasmaram universitários que o país nunca havia antes conhecido e que se projetaram internacionalmente, para se instalar a rotina mais comezinha e banal. Bastaria citar os nomes de Carlos Chagas, Adolpho Lutz, Gaspar Vianna, Henrique Aragão, Arthur Neiva, Gomes de Faria, Rocha Lima, Lauro Travassos, Costa Lima, Miguel Ozorio de Almeida, Genesio Pacheco, Fabio Werneck, Walter Oswaldo Cruz, Magarinos Torres e Thales Martins, para lembrar apenas alguns dos falecidos ou, como os dois últimos, há anos aposentados e afastados de qualquer atividade científica. 
É verdade que não é de agora que tal miopia cultural tem sido tentada. Mas somente quando se fizeram calar as últimas vozes capazes de lutar pelo antigo ideal, capazes de chamar a atenção para o crime de lesa-pátria que se estava programando, capazes de mostrar a irracionalidade do objetivo visado, foi que, com o favorecimento de um ambiente propício, gerado em boa parte pelo medo, se tornou possível levar uma instituição nobre - embora em declínio, mas com potencialidade e recursos bastantes para recompor-se e renovar-se - ao beco sem saída em que se encontra, a enfrentar projetos prioritários superiores à sua capacidade de execução e a tentar pesquisa dirigida e utilitária sem respaldo em ciência básica. Destruíram-se laboratórios de fisiologia, de bioquímica, de farmacologia, de patologia; produziram-se desincentivos ao trabalho de entomologia e helmintologia sem conotação com as linhas prioritárias, ameaçados que estão seus cultores nessa área de grande relevo e tradição na instituição, de ficarem sem as magníficas coleções de insetos e helmintos produzidas desde a fundação do Instituto, com a notícia que se propala de que serão doadas a outras instituições.

O motivo continua a ser pueril. Não consideram dignos de figurar no Instituto Oswaldo Cruz, por exemplo, os insetos representativos dos grupos zoológicos que não encerram representantes de 
interesse médico, ignorando que a ciência é uma só e dela deriva a aplicação. O estímulo exclusivo à aplicação gera "técnicos" sem capacitação e poder criador, incapazes de ter ideias ou deflagrar novos conhecimentos.

Só falta mesmo mutilar a Biblioteca e transferir para outras todo o acervo, que é bastante grande e valioso, dos livros e publicações periódicas e de referência, que não tenham interesse direto com a pesquisa ou a técnica nas áreas prioritárias estabelecidas. Por que não o fazem? Por que a incoerência? 


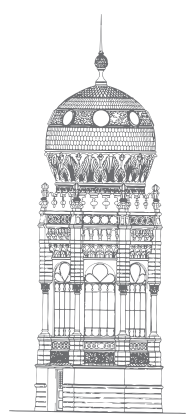

movimento militar de 1964 encontrou o Instituto Oswaldo Cruz dirigido por Joaquim Travassos da Rosa, um cientista que tinha feito sua carreira no Instituto Butantã em São Paulo e que substituíra Tito Arcoverde de Albuquerque Cavalcanti no início do governo Jânio Quadros.

Joaquim Travassos ostentava passado de pesquisa continuada e havia contribuído com valiosos trabalhos, principalmente na área das rickettsioses humanas. Mas isso não impediu que o governo Castelo Branco o substituísse, logo em junho, por F. P. Rocha Lagoa, um médico medíocre que também pertencia aos quadros do Instituto, mas não possuía nenhuma credencial como pesquisador.

Costumo dizer aos meus alunos que a carreira de cientista, antes de mais nada, exige a demonstração de capacidade que o ato final de sua atividade impõe. O trabalho científico sempre deve terminar numa publicação, pois só se valorizam os resultados que ficam expostos à coletividade, que assim 
pode julgá-los, aceitando-os e aproveitando-os ou rejeitando-os. O pesquisador científico, para dessa forma intitular-se, necessita ter um currículo que o credencie, e suas publicações científicas constituem o documento natural dessa comprovação. Se os trabalhos publicados são bons, valiosos, estará firmado o conceito de seu autor, mas se não representarem nada de valioso (ou se não existirem) também estará firmado o mau conceito do intitulado pesquisador, que dessa forma terá deixado o documento negativo que passará a caracterizar o seu curriculum vitae.

Eis por que não é difícil de afirmar que F. P. Rocha Lagoa não possuía as credenciais necessárias ao bom pesquisador, conceito que se generalizaria a tal ponto que até os órgãos de segurança o rotulavam de "mau pesquisador e mau administrador", embora salientando suas qualidades de ativo anticomunista, uma nítida provocação macarthista.

Um simples fato, porém muito importante pelo que representa para o perfil do vilão desta história, aconteceu logo nos primeiros dias depois de sua posse. Visitava ele os laboratórios de entomologia, então localizados no $2^{\circ}$ andar do edifício-sede, logo acima das instalações da diretoria, e conversava com os cientistas que ali se encontravam, Hugo de Souza Lopes, Sebastião de Oliveira e eu próprio, discorrendo sobre seus planos, para terminar 
declarando que eles se "baseavam na orientação do Pentágono". Surpreso com a afirmativa, ainda pude conseguir fôlego para dizer-lhe que não sabia que o Pentágono possuía planos para direção de instituições científicas no Brasil. E não pude deixar de emitir sonora gargalhada, quando Lagoa afirmou doutoralmente que aquele organismo norteamericano possuía diretivas para todo e qualquer caso que se apresentasse em qualquer parte do mundo. Havia ele regressado pouco tempo antes, de uma visita de uma semana que os alunos de sua turma na Escola Superior de Guerra haviam feito aos Estados Unidos.

Os três interlocutores do novel diretor estariam entre os dez cientistas cassados seis anos depois desse episódio.

Mas ao assumir o cargo de diretor do Instituto Oswaldo Cruz, Rocha Lagoa já encontrou iniciadas as duas inquirições que a revolução de 1964 ali havia instaurado. Um dos inquéritos foi praticado por uma subcomissão de investigações constituída pelo prof. Olympio da Fonseca Filho (seu presidente), pelo médico José Fonseca da Cunha e pelo advogado José Venancio de Moura e se subordinava à Comissão de Investigações do Ministério da Saúde presidida pelo Dr. Alberto Jorge Ferreira. O outro foi um IPM presidido pelo General Aluisio Andrade Falcão que, concomitantemente, tratava dos mesmos assuntos 
do seu homólogo civil, ambos se superpondo em seus objetivos, isto é, visavam apurar subversão e corrupção. Nos dois casos foram ouvidos quase todos os cientistas, médicos e pesquisadores, além de vários outros funcionários.

Uma terceira investigação, para prestar esclarecimentos sobre os auxílios recebidos de entidades governamentais ou particulares, nacionais ou estrangeiras, foi realizada sob a presidência do próprio Presidente da Comissão de Investigações do Ministério da Saúde e visou alguns cientistas, justamente aqueles que mais intensamente usavam os auxílios que aplicavam em seus trabalhos. Os inquiridos foram também questionados sobre seu pensamento político ou atitude ideológica.

Antes mesmo de serem iniciados tais inquéritos, vários cientistas que exerciam funções de chefia (dois chefes de divisão, Walter Oswaldo Cruz, da Divisão de Patologia, e Herman Lent, da Divisão de Zoologia; e seis chefes de seção, J. F. Teixeira de Freitas, Henrique Velloso, Haity Moussatché, Fernando Ubatuba, Hugo de Souza Lopes e Masao Goto) foram afastados dessas chefias pelo Ministro da Saúde Raymundo de Britto, que assim proclamava um prejulgamento justamente no momento em que se iniciavam os inquéritos. Pois, ao dar posse ao novo diretor, que nomeara, disse o seguinte (Correio da Manhã, de 24/04/1964): 
Se é verdade que não há fronteiras para a ciência, também é exato que há fronteiras para os cientistas. As ideias exóticas que em Manguinhos foram infiltradas serão banidas definitivamente, porque o nosso País precisa de homens que nos ajudem a acabar com o sofrimento do povo, e não de elementos cujo único fito é destruir a liberdade, esfacelando o regime democrático. Manguinhos de amanhã será uma colmeia de trabalho, e não o que queriam alguns: um foco de ideias subversivas. O Instituto Oswaldo Cruz terá todos os recursos de que carece para suas pesquisas.

O tempo se encarregou de desmenti-lo, e não seremos nós que nos preocuparemos com esse detalhe, cuja evidência é irrespondível. É só olhar para o Instituto Oswaldo Cruz de hoje.

Com esse respaldo a seus objetivos obscurantistas, a pressão exercida sobre a pesquisa no Instituto foi sendo imposta acentuadamente. $\mathrm{O}$ novo diretor discriminava, agredindo os que não lhe eram simpáticos, não proporcionando recursos para a pesquisa, impedindo que os auxílios já obtidos (Fundação Ford, Fundação Rockefeller, National Institutes of Health etc.) fossem diretamente entregues aos já escolhidos por essas organizações, querendo ele próprio se constituir em selecionador e distribuidor.

Em fins de 1964, a Imprensa falava em terror cultural, também exercido no Instituto Oswaldo Cruz, onde vários cientistas eram pressionados, entre eles o Dr. Walter Oswaldo Cruz (e seus assistentes), que 
tivera o seu laboratório praticamente destruído e seus alunos dispersados.

No início de 1965, concluídas as investigações e sem notícia da apuração de qualquer delito, alguns dos cientistas representaram junto ao Ministro da Saúde, Dr. Raymundo de Britto, informando inclusive à imprensa sobre o que se passava no Instituto. Enviaram representações, também, à Academia Brasileira de Ciências e ao Conselho Nacional de Pesquisas sobre o perigo que corria Manguinhos e a pesquisa científica, sugerindo a criação do Ministério da Ciência e Tecnologia, como pleiteado em outros setores.

No Correio da Manhã (03/01/1965), dizia o Prof. H. Moussatché:

As direções dos órgãos culturais estão cada vez mais esmeradas no combate àqueles contra os quais foram levantadas suspeitas e acusações. O combate é sutil e, se permanecer, provocará dentro de algum tempo uma sensivel redução no rendimento do trabalho de pesquisa.

De Herman Lent publicava o Correio da Manhã (14/01/1965) a seguinte opinião:

Há quem combata a ideia do Ministério da Ciência e Tecnologia temendo que o novo ministro venha a ser um político, levando a política para o meio científico. Mas esse temor não procede porque os ministros são geralmente politicos, sem que isso traga implicações ao trabalho técnico de cada ministério. Todos sabem que o melhor Ministro da 
Guerra que já tivemos foi Pandiá Calógeras, que não era um técnico na arte militar, mas um político.

E continuava o pesquisador (Correio da Manhã, 02/02/1965), com palavras proféticas, a combater o caminho para o qual se empurrava a nobre instituição, que hoje se vê a braços com a ausência de pesquisadores nacionais capazes de realizar até a pesquisa aplicada que se resolveu exigir do Instituto Oswaldo Cruz:

Não acreditamos que o país não possa entender o significado de uma instituição de pesquisa científica, escola de alta cultura ou de pós-graduação, sem preocupações forçadas de aplicação imediata. O homem comum já vê e sente o que a ciência pode proporcionar ao progresso e sabe que o desenvolvimento dos países está condicionado ao valor e à capacidade de seus cientistas.

No terreno das ciências biológicas em geral, o Instituto Oswaldo Cruz ocupa papel de relevo. Por que, então, cercear seu desenvolvimento, bitolar suas diretrizes, prendendo-o a um Ministério de objetivos eminentemente utilitários? Já se foi o tempo em que a muitos pareceria luxo manter o trabalho da ciência básica, porém hoje até os leigos sabem que os pesquisadores não se improvisam de um dia para o outro. Sua formação é demorada e dispendiosa, e as aplicações práticas de seus conhecimentos se revelam quando as necessidades surgem subitamente. Ninguém ignora que toda improvisação é perigosa e que o patrimônio cultural que Manguinhos representa deverá ser preservado pelos brasileiros de hoje para entregá-lo às gerações vindouras. 
Não é freando linhas de trabalho, impossibilitando o desenvolvimento de pesquisas iniciadas há longo tempo, impedindo a especialização de jovens e obrigando-os a cursos de formação inexpressivos, impondo prioridades danosas à liberdade de pesquisa, cerceando projetos estimulados por organismos de cúpula, como o Conselho Nacional de Pesquisas; não é com isso que as administrações construirão algo de bom e duradouro.

Em janeiro de 1966, já agora sob acusação direta do Dr. F. P. Rocha Lagoa, a Seção de Segurança do Ministério da Saúde intimou 16 cientistas apontados pelo diretor, que os discriminara em 4 grupos, a prestarem informações sobre a acusação de "conspirar em seus laboratórios". O tenente da PM, Hilton Queiroz Actis, informava a cada cientista que se tratava apenas de uma inquirição preliminar; não era inquérito policialmilitar ou administrativo. E informava que tinha sido originada pelo órgão de segurança da Marinha, o Cenimar, mostrando o ofício respectivo em que se dizia textualmente que a informação solicitada - a autoria de um manifesto sobre a situação da Universidade de Brasília - deveria ser obtida do diretor do Instituto Oswaldo Cruz, que, embora "mau administrador e mau pesquisador, era ativo anticomunista".

Dessa forma, os 16 cientistas apontados pelo diretor tiveram a oportunidade de defender-se e, ao mesmo tempo, acusar a administração do Instituto. Basta somente referir que uma das acusações formuladas pelo diretor era a de que os cientistas defendiam a 
criação do Ministério da Ciência, atitude subversiva para ele, que depois foi incluída na Lei que estabeleceu a Reforma Administrativa do país, não executada totalmente até agora.

De todos esses episódios nunca apareceram as conclusões finais; constatava-se, no entanto, que eram processos arquivados, pois o tempo decorrido levava a essa interpretação. Informações verbais prestadas a alguns cientistas, não só pelo Dr. Alberto Ferreira, como também pelo General Aluisio Falcão e pelo Capitão Pedro Augusto Lisboa Baptista, encarregados dos aludidos inquéritos, diziam não ter sido encontrado fundamento algum para indiciação. Nessa mesma época, um dos cientistas que depois veio a ser cassado (Augusto Perissé) necessitou ir à França atendendo a convite desse país e, impedido por Rocha Lagoa, requereu uma certidão que o General Golbery do Couto e Silva, então chefe do Serviço Nacional de Informações, despachou nos seguintes termos:

No relatório final da extinta Comissão Geral de Investigações, o nome do requerente não figura entre as pessoas em relação às quais a CGI julgou aplicável as sanções do art. 7 do Ato Institucional. A subcomissão da Comissão de Investigações do Ministério da Saúde, que procedeu à Investigação Sumária no Instituto Oswaldo Cruz, cujos autos encontram-se em poder do SNI, nada apurou relativamente à prática de atividades subversivas, corrupção ou improbidade pelo requerente. 
Persistia, entretanto, o diretor Rocha Lagoa em seus objetivos de destruir os cientistas que não concordavam com seus desmandos e repeliam publicamente suas acusações, protestando junto a instituições científicas, órgãos de assessoramento e órgãos de informação, pela discriminação que sofriam em prejuízo de suas atividades científicas. A direção do Instituto impedia de todas as formas qualquer auxílio que pudesse vir a ser concedido do exterior ou de outros órgãos governamentais. 


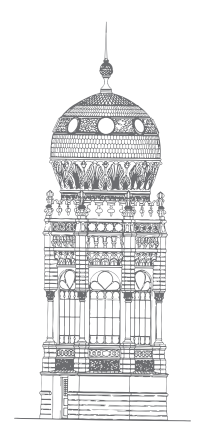

pesar de todos os impedimentos e pressões - Ios cientistas continuavam a trabalhar, com esperanças de melhores dias. Publicavam os resultados de suas pesquisas e os apresentavam a sociedades científicas, congressos, simpósios.

Em junho de 1965, o Ministro Roberto Campos, do Planejamento, convidou vários cientistas para uma troca de ideias. Estavam presentes: Arthur Moses e Antonio Couceiro, do Conselho Nacional de Pesquisas; Lelio Gama, do Observatório Nacional e do CNPq; José Cândido de Carvalho, do Museu Nacional; Carlos Rizzini, do Jardim Botânico; Walter Mors, do Instituto de Química Agrícola e Faculdade de Farmácia; João Perrone, do Instituto Tecnológico; Aristides Leão, do CNPq e do Instituto de Biofísica; Jacques Danon, do Centro de Pesquisas Físicas; Walter O. Cruz, Herman Lent, H. Moussatchée Tito Cavalcanti, do Instituto OswaldoCruz, oúltimo também doCNPq. Aípudemos expor vários pontos de vista sobre a proteção que se fazia necessária às instituições de ciência e tecnologia, defendendo a criação do Ministério da Ciência. 
Decorreu desta forma o governo Castelo Branco e a gestão no Ministério da Saúde do Dr. Raymundo de Britto, que, apesar de prejulgar os resultados dos inquéritos e de sofrer a insistência do diretor do Instituto Oswaldo Cruz, não via elementos, embora pressionado, para afastar os cientistas que enfrentavam as iras de Rocha Lagoa.

O embate inicial sofreu-o exatamente um dos filhos de Oswaldo Cruz, cujo laboratório havia chegado a ter 58 pessoas em atividade. Walter Oswaldo Cruz formara 15 estudantes, batalhando por instalações, por material de natureza vária, por bolsas de estudo e até por compreensão. Conseguira muito do que desejava até que todo um prejulgamento de suspeitas infundadas foi sistematicamente deflagrado visando à liquidação da pesquisa básica. Os inquéritos, as indagações, punições, circulares, restrições, pressões, transferências, transformaram o clima da instituição e se refletiram nos laboratórios mais produtivos.

Walter Oswaldo Cruz, ferido por tantas agressões, morreu a 3 de janeiro de 1967. Não tenho dúvidas de que estaria entre os cassados de Manguinhos se tivesse sobrevivido.

A Lei que fixou os termos da chamada Reforma Administrativa, baixada nos últimos dias do governo Castelo Branco, previa a nomeação de um Ministro Extraordinário da Ciência e da Tecnologia, ao qual se vinculariam, desde logo, o Conselho Nacional 
de Pesquisas, a Comissão de Energia Nuclear e os órgãos de atividades espaciais. Nomeado o Ministro, imaginávamos que suas primeiras atividades 0 levariam a constituir o Ministério, selecionando os órgãos mal colocados ou desajustados nos atuais Ministérios. Só então seria possível a boa coordenação de iniciativas e providências capazes de instalar e intensificar as atividades científicas e tecnológicas que se programassem, não apenas de interesse científico, mas, também, econômico e social.

Um Ministério obrigado a pensar e a agir em função dos interesses da pesquisa científica e tecnológica não deixaria de trazer grandes vantagens. Compreende-se que as instituições científicas submetidas aos Ministérios da Agricultura ou da Saúde, por exemplo, estejam relacionadas às atividades primárias desses ministérios, a eles obedientes e devendo atenção. E isso faz com que pareça ter mais valor para o diretor do Jardim Botânico o estabelecimento de uma área para estacionamento dos automóveis dos visitantes do jardim, do que a manutenção de um local para observação da vida de determinadas plantas ou um laboratório de pesquisa em fisiologia vegetal. Ou que possa ser considerada posição incapaz de ser discutida, a do imenso acervo e potencial do Instituto Oswaldo Cruz destinado a fabricar vacinas em detrimento de atividades de pesquisa criadora. A esse respeito divulgava- 
se, à época, um valioso estudo de Ezio Fundão (Jornal Brasileiro de Medicina, maio de 1966) onde, ao falar de Manguinhos, dizia textualmente o autor:

Este consagrado Instituto de Pesquisa médica deve voltar à sua finalidade superior de pesquisa pura, e deixar de ser a "fábrica de vacinas do Governo". Tem que ser o centro científico para o qual o gênio de Oswaldo Cruz o projetou, e não um estabelecimento oficial em que tantos e ilustres cientistas se estiolam, sem recursos, e assistem, impotentes, a todos os titulares, que pelo Ministério da Saúde já passaram, destruir o único centro médico de pesquisa científica de renome no mundo científico, teimando ou não sabendo que o estão matando ou transformando em uma "quitanda".

Nos últimos anos, muitos cientistas de valor e de atividade constante se viram marginalizados, não só porque tinham servido em postos científicos de direção de governos passados, como por se manifestarem defensores de conceitos e providências, como as que estamos discutindo, que impulsionassem o trabalho científico, dinamizassem e bem situassem essas atividades.

Recebemos, assim, o apodo fácil de "subversivos", respondemos a inquéritos humilhantes e desprimorosos, obrigados a desmascarar acusadores, e fomos previamente eliminados dos conselhos, das direções técnicas, da oportunidade de formar jovens pesquisadores, objetivamente apontados com desconfiança propositalmente estabelecida e que nunca chegou a ser confirmada. 
Certos setores governamentais deveriam meditar sobre suas contradições e os vaivéns de suas atividades, de um lado incentivando o trabalho dos pesquisadores, de outro entravando-os, opondo restrições de ordem vária ao livre acesso dos jovens que procuram fazer carreira científica; de um lado, instando pelo retorno dos que se encontram no estrangeiro, de outro, cruzando os braços aos reclamos por melhores condições de trabalho; de um lado, acenando com melhorias de natureza econômica, de outro, tornando instável e precário o regime de tempo integral.

$\mathrm{Na}$ verdade, não mais deveriam ser admitidos diretores de instituições científicas não entrosados com os pesquisadores, que discriminam entre uns e outros por motivos inconfessáveis e odiosos, que estabelecem como premissa para obtenção de estágios de estudantes o beneplácito inicial de órgãos de informação policial, que impedem a pesquisa livre de obstáculos e a plena liberdade intelectual, que recusam e cancelam os auxílios de fundações internacionais de ajuda à pesquisa, ou que estimulam a mediocridade onde se veem como num espelho.

A existência de um Ministério especializado, afim ao da Educação e Cultura, deveria proporcionar um clima que nos falta, em que ao lado das necessidades materiais de cada cientista fosse possível prever e prover as necessidades ambientais, o clima para suas atividades de trabalho, o laboratório com recursos 
de aparelhagem e modernização exigidos e verbas regulares de manutenção, a compreensão de que a insistência pela obtenção desses requisitos não seja encarada como subversão.

Por esses motivos, por todas as dificuldades que encontram, saem do país os cientistas à procura do que aqui não lhes é proporcionado; e voltarão, devem voltar, pois fazem falta, já que somos muito poucos. Nós, os que aqui permanecemos, os cientistas exilados em nosso próprio país, deveríamos continuar a lutar para mostrar aos governantes que não basta solicitar o regresso quase impossível dos que já se foram, principalmente sem lhes oferecer sequer a segurança de uma transformação de tratamento; é preciso impedir que outros sigam o mesmo caminho e, ainda, o que é mais importante, é preciso estimular entre os jovens o interesse por essas atividades, mostrandolhes o seu valor para o país, e também garantindo-lhes tudo aquilo que se tornará necessário para que possam produzir em ritmo acelerado, certos de que estarão amparados, repito, não só em suas necessidades materiais, como também, e principalmente, em seus justos anseios por ambientes de trabalho honestos e livres, onde as atividades científicas sejam respeitadas e livres da influência atrasada e deletéria da burocracia e da ignorância.

Com a nomeação do Dr. Leonel Miranda para Ministro da Saúde do governo Costa e Silva, tentou 
novamente o Dr. Rocha Lagoa, que continuava no cargo, eliminar os cientistas, alvo de suas hostilidades. E o fez por várias vezes e sob alegações infundadas, que não surtiram efeito. Igualmente, tentou prejudicar os auxílios concedidos pelo Conselho Nacional de Pesquisas, de cujo Conselho Deliberativo fazia parte como representante do Ministério da Saúde. Ali, sua figura desprestigiada e vingativa ficou bem conhecida.

Contudo, em outras áreas do governo a atuação de alguns dos cientistas que vieram a ser cassados era observada de forma diferente. Em junho de 1967, o Ministro Magalhães Pinto, das Relações Exteriores, incluíra os nomes de Tito Cavalcanti, Haity Moussatché e Herman Lent como convidados ao almoço-reunião de cientistas que escolhera, aos quais desejava ouvir sobre os problemas relacionados ao êxodo de numerosos cérebros que considerava úteis à nação. Entre os convidados encontravam-se: Arthur Moses e Aristides Leão, da Academia Brasileira de Ciências; Antonio Couceiro, presidente do Conselho Nacional de Pesquisas; J. Leite Lopes, professor de física da UFRJ; Clodowaldo Pavan, professor de genética da USP; Leopoldo Nachbin, do Instituto de Matemática Pura e Aplicada; Marcelo Damy de Sousa Santos, do Instituto de Energia Atômica, de São Paulo; Amadeu Cury, diretor do Instituto de Microbiologia da UFRJ; Hervasio de Carvalho, diretor do Centro Brasileiro de Pesquisas Físicas; Jacques Danon, do mesmo Centro; 
Andrade Ramos, do Departamento Nacional de Produção Mineral.

Na ocasião, apresentamos várias sugestões escritas que revelavam nossa preocupação com o declínio de instituições diversas, como Instituto Butantã e Instituto Biológico, em São Paulo, Instituto Oswaldo Cruz, Jardim Botânico e Museu Nacional, no Rio de Janeiro.

Em 16 de outubro de 1967, proferi conferência na Faculdade de Farmácia e Bioquímica, a convite do centro estudantil, sob o título "Dificuldades da pesquisa científica no Brasil", sempre chamando atenção para a necessidade de amparar as atividades científicas, estimulando a ciência básica.

Em fins de 1967, a biblioteca do Instituto Oswaldo Cruz recebeu, por doação, um exemplar da conferência realizada na Escola Superior de Guerra por um seu exaluno, Francisco de Paula da Rocha Lagoa, ele próprio o doador do exemplar que na biblioteca recebeu o $\mathrm{n}^{\circ}$ 29.703.

Tornado público dessa forma o documento, que se intitula "O panorama da saúde e o Brasil", pude lêlo, surpreendendo-me com os numerosos erros ali impressos, após veiculados no auditório daquela Escola pelo conferencista.

E tive a imprudência ou a ingenuidade, depois vim a sabê-lo, de dirigir-me ao ilustre Comandante da Escola, General Augusto Fragoso, hoje Ministro do Superior 
Tribunal Militar, e dando relevo ao motivo pelo qual pretendi colaborar com a direção da Escola, escrevi:

É meu intento, ao me dirigir a Vossa Senhoria, apontar os numerosos erros que se encontram em tal publicação, que compromete a Escola comandada por Vossa Senhoria, não só por ter formado tal aluno, quanto por the atribuir qualidade e autoridade de conferencista. E ao fazer essa afirmação não estou me excluindo de idêntico vexame, pois pertenço ao quadro de pesquisadores do Instituto Oswaldo Cruz, do qual o Dr. Rocha Lagoa é o atual diretor.

Assim, estamos irmanados na mesma situação, nós que pertencemos ao Instituto Oswaldo Cruz e que sentimos de perto o desprestígio a que está sendo lançada esta importante instituição nacional, e Vossa Senhoria e seus comandados que visam a formar uma elite integrada por civis e militares, no esforço comum de encontrar solução para os problemas nacionais de relevo.

Minha representação tinha 9 páginas datilografadas e apontava 3 gêneros de erros: um deles caracterizava a cultura geral do seu autor, a maneira de escrever, os conceitos de natureza geral que emitia, o tipo de informação que pretendia divulgar; continha noções falsas de aritmética e de geografia de nível ginasial e redação confusa, acrescida à ligeireza da informação, sem a necessária precisão que se exige de pessoa que se apresenta como pesquisador e diretor de uma grande instituição nacional de ciência. $\mathrm{O} 2^{\circ}$ gênero se referia especificamente ao tipo de informação médica e sanitária, que divulgava erradamente e com dados 
tomados de autores que não cita, nem indica. $\mathrm{O} 3^{\circ}$ gênero se localizava nas ilustrações que apresentou, reproduzidas sem indicação de origem, estabelecendo falta de ética injustificável e clamorosa.

Foi pena que não tivesse eu conseguido sensibilizar o então Comandante da Escola Superior de Guerra, General Augusto Fragoso, hoje talvez mais compreensivo. Pois, se assim tivesse acontecido, possivelmente teríamos libertado Manguinhos de seu algoz. Dizia eu, então, em carta ao General, hoje Ministro do Superior Tribunal Militar:

Talvez seja do seu conhecimento que no Instituto Oswaldo Cruz existem pesquisadores que há vários anos vêm considerando a má colocação dessa instituição no Ministério da Saúde e que advogam, pleiteiam e promovem a urgência da criação do Ministério da Ciência e Tecnologia, onde também diversas outras instituições carentes de amparo e estímulo e de grande importância para a nação possam sobreviver e produzir trabalho científico de boa qualidade.

Temos procurado de todas as maneiras fazer com que as autoridades governamentais compreendam os objetivos que nos movem e os anseios que temos, que se estendem e ampliam ao desenvolvimento do trabalho científico no país. Conferências, entrevistas a jornais, memoriais, uma variedade ativa de informações tem sido divulgada.

Em relação ao Instituto Oswaldo Cruz, entregue há mais de 3 anos à direção de um ex-aluno da Escola Superior de Guerra, temos procurado mostrar o prejuízo que sua administração vem causando ao prestígio dessa grande instituição nacional 
como casa de ciência e que agora culmina com a conferência profundamente desmoralizadora por ele proferida.

Nunca foi minha intenção escrever nada que pudesse ser hostil à Escola Superior de Guerra, nem mesmo sequer pensar em termos impróprios a respeito dessa instituição. Considerei, ao contrário, que ela merecia que eu fizesse a seu Comandante a contribuição construtiva que lhe dirigi. E a forma por que o fiz, transmitindo-lhe através de seu próprio filho, refletia exatamente a minha preocupação em deixar inteiramente em suas mãos a opção que desejasse tomar.

É iniludível, contudo, que só pude conhecer os termos do documento reservado, porque ele foi depositado pelo seu autor, o conferencista, em biblioteca pública, a do Instituto Oswaldo Cruz, onde conserva o n 29.703 e foi desdobrada em várias fichas por bibliotecárias que dele, pelo menos, tomaram conhecimento a fim de classificá-lo pelos assuntos de que trata. Qualquer pessoa poderá, desde aquela data, consultá-lo, apesar de Reservado e destinado a ser distribuído aos estagiários, como vim a saber posteriormente.

Em março de 1969, ainda na gestão do Ministro Leonel Miranda, o Dr. F. P. Rocha Lagoa, agora Supervisor da Entidade de Pesquisa do Ministério da Saúde, afirmou aos chefes de divisão e de seção do Instituto Oswaldo Cruz que não desejava ser o "coveiro" da casa que ele dirigira até há pouco tempo, quando fora nomeado 
para o elevado cargo que ora exercia, solicitando o apoio dos colegas para evitar, segundo disse, a destruição do Instituto programada no Colegiado de Supervisores.

Vinte pesquisadores do Instituto Oswaldo Cruz se dirigiram, então, ao Dr. Aristides Limaverde para manifestar ao aludido Colegiado seus pontos de vista em relação ao que sabiam ter sido discutido:

1) Aplaudindo, no que toca ao Instituto Oswaldo Cruz, a supressão do encargo da produção de medicamentos.

2) Aplaudindo a supressão dos encargos de ensino curricular ou de extensão representado pelo curso ministrado, obsoleto como estava orientado, sugerindo que a formação e a qualificação de novos pesquisadores se fizesse através de programas de pós-graduação, para cujo fim o Instituto tinha então mandato universitário da Universidade Federal do Rio de Janeiro.

3) Considerando que as atividades de pesquisa deveriam ser exercidas em sentido amplo e com o indispensável grau de liberdade no campo da investigação médico-biológica, quer no sentido de ciência básica, quer com significação médico-sanitária ou de medicina aplicada.

Rocha Lagoa não foi realmente o "coveiro" de Manguinhos. Foi o "assassino" da instituição. O "cadáver" continua insepulto na Avenida Brasil. 


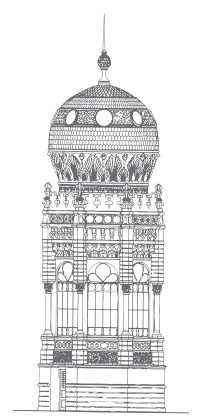

U

ma vez nomeado Ministro do Governo Médici, viu seu caminho ainda obstado pelo Chefe da Seção de Segurança do Ministério da Saúde e Supervisor da Administração, General Armando Barcellos, que permanecera nos cargos que assumira na gestão Leonel Miranda e era contrário às punições propostas. Foi necessário a Lagoa afastálo para que seu objetivo de tantos anos pudesse ser atingido. Mesmo assim, não foi sem protesto que o General Barcellos entregou o cargo, pois reuniu cerca de 300 funcionários na sede do Ministério, então no Edifício do Clube de Engenharia, e, referindo-se desabonadoramente ao ministro, disse que iria dirigir-se às autoridades "para contar o que está se passando no Ministério da Saúde" (Tribuna da Imprensa, março 1970).

Afastado desse último empecilho, com a exoneração do militar, que é hoje o chefe de segurança da Comissão Nacional de Energia Nuclear, estava livre o caminho para a execução do 
que logo veio, e com data de $1^{\circ}$ de abril de 1970 . O Diário Oficial, de 2 de abril, publicou o decreto suspendendo os direitos políticos por dez anos de: Haity Moussatché, Herman Lent, Moacyr Vaz de Almeida, Augusto Cid de Mello Perissé, Hugo de Souza Lopes, Sebastião José de Oliveira, Fernando Braga Ubatuba e Tito Arcoverde Cavalcanti. Tudo como resolução do Presidente da República e de acordo com o art. 182 da Constituição e na forma do disposto no art. $4^{\circ}$ do Ato Institucional $\mathrm{n}^{\mathrm{o}} 5$, tendo em vista indicação do Conselho de Segurança Nacional. Assinaram: Emílio G. Médici; Alfredo Buzaid; Adalberto de Barros Nunes; Orlando Geisel; Mario Gibson Barboza; Antonio Delfim Netto; Mario David Andreazza; L. P. Cirne Lima; Jarbas G. Passarinho; Julio Barata; Marcio de Souza e Mello; Antonio Dias Leite Jr.; Marcus Vinícius Pratini de Moraes; João Paulo dos Reis Velloso; José Costa Cavalcanti; Hygino C. Corsetti. Escondida entre essas assinaturas encontrava-se também a de F. Rocha Lagoa, que promovera e lutara pela cassação.

O Jornal do Brasil, em seu editorial de 4 de abril, sob o título "Servidores da Vida" comentava o ato, dizendo:

... não se sabe, com exatidão, por quê. Sabe-se que não são terroristas e que nem pertencem ao Esquadrão da Morte. Trabalham em laboratórios, e o correto seria talvez dizer 
que pertencem ao diminuto esquadrão dos que pesquisam a vida entre nós. Todos trabalham há muitos anos em Manguinhos. Todos têm nome conhecido no mundo da ciência internacional. Estariam esses cientistas tramando uma guerra bacteriológica? Nesse caso, deviam estar presos, e não apenas sofrendo uma degradação da sua cidadania. A notícia das cassações mergulha o país em perplexidade. De certo só se sabe que em breve os punidos estarão em Harvard, em Cambridge ou na Sorbonne, e que o Brasil terá ficado mais pobre.

Em seguida, o Diário Oficial de 6 de abril publicou decretos de aposentadoria dos mesmos, adicionando os nomes de Masao Goto e Domingos Arthur Machado Filho, também do Instituto Oswaldo Cruz. Estas aposentadorias foram assinadas por Médici e Lagoa.

Sem falar no que representa para uma instituição científica a perda física de dez de seus experimentados componentes, considerando, ainda, que seu quadro de pesquisadores não atingia a uma centena $e$, desses, a grande maioria não se dedicava à pesquisa propriamente dita: sem falar, ainda, que existe impedimento frontal de aproveitamento dos cientistas em outras instituições ou universidades, a gravidade imediata do ato, para o país, pode ser assim resumida:

1) Extinção sumária de várias linhas de pesquisa.

2) Eliminação de estagiários e alunos ligados aos cientistas afastados. 
3) Perigo de dispersão e liquidação do patrimônio incalculável de coleções de insetos e helmintos (coleção do IOC, coleção Costa Lima, Coleção F. Zikán, coleção Adolpho Lutz, coleção Arthur Neiva, coleção Lauro Travassos, coleção César Pinto, coleção Fábio Werneck, coleção Henrique Aragão, coleção Octávio Mangabeira Filho).

4) Extinção do Laboratório de Neurofisiologia, ligado à Organização Internacional do Estudo do Cérebro.

5) Perigo de destruição de uma grande criação em laboratório de espécies diferentes de triatomíneos (insetos transmissores da doença de Chagas), mantidos vivos há cerca de 40 anos.

6) Suspensão das atividades desse mesmo laboratório em cooperação com a Organização Mundial de Saúde para o teste de inseticidas Contra "barbeiros".

7) Impedimento da colaboração que já estava assentada nos cursos de pós-graduação: de Entomologia, na Universidade Federal do Rio de Janeiro; de Entomologia, na Universidade Federal do Paraná; de Medicina Tropical, na Universidade Federal do Rio de Janeiro.

8) Impedimento da colaboração nos cursos da Fundação Escola de Saúde Pública.

9) Cessação da colaboração com a Universidade 
Federal de Minas Gerais e seus cursos de pósgraduação em Parasitologia.

10) Impedimento da colaboração estabelecida com o Instituto Nacional de Pesquisas da Amazônia.

11) Impedimento da colaboração com o Conselho Nacional de Pesquisas: três dos cientistas eram professores-conferencistas e dois eram bolsistas.

12) Cessação da colaboração com a Universidade Federal Rural do Rio de Janeiro (Departamento de Fisiologia e Bioquímica).

13) Cessação da colaboração com a Escola de Medicina e Cirurgia (Parasitologia).

14) Cessação da colaboração com a Universidade de São Paulo (Departamento de Química, em Ribeirão Preto).

15) Cessação da colaboração com o Laboratório de Controle de Medicamentos Veterinários, do Ministério da Agricultura.

16) Dificuldades na colaboração com o Hospital Central do Exército, Policlínica do Exército, INPS e Hospitais da Suseme, pelo Centro de Diagnóstico Micológico no diagnóstico das micoses humanas.

17) Cessação das pesquisas sobre substâncias citotóxicas de origem fúngica (para utilização na terapêutica do câncer). 
As acusações de comunismo no Instituto Oswaldo Cruz se iniciaram com base em um episódio acontecido em 1946, um telegrama dirigido ao então Senador Luiz Carlos Prestes e que nos habituáramos a ver ressurgir quando algum interessado o promovia, porém com seus termos odiosamente modificados.

Esse telegrama, divulgado pelo jornal Tribuna Popular em 17/04/1946, de fundo patriótico e nacionalista, explicitamente indicado como enviado "independentemente de caráter partidário", aplaudia a manifestação do Senador em defesa do território nacional, no Nordeste, contra a continuação, após o término da Segunda Guerra Mundial, de sua ocupação por bases e tropas estrangeiras.

Em todas as ocasiões em que se procurou atingirnos, e foram várias, sempre se pretendeu ligá-lo a outra declaração atribuída a Prestes a respeito de sua atitude em relação à possibilidade de uma guerra entre o Brasil e a União Soviética. Transformava-se, deste modo, o sentido inconfundível do telegrama assinado, para fazê-lo de apoio a país estrangeiro eventualmente em guerra contra o Brasil. Não vejo, porém, como conciliar esta asserção falsa, que sempre desmentimos, com os termos claros do telegrama: "Em defesa do nosso povo e da soberania e integridade do território nacional" 
(veja reprodução facilitada pelo Prof. Olympio da Fonseca Filho, no Jornal do Brasil de 19/02/1978).

É justamente o Prof. Olympio da Fonseca Filho, o mais constante divulgador do malfadado telegrama, que surge, pela primeira vez contra mim, por ocasião de um pedido de concessão de passagem aérea que fiz, no já distante ano de 1952, ao Conselho Nacional de Pesquisas, para atender ao convite da Universidade do Chile que desejava que se verificasse a existência no norte daquele país, no deserto de Atacama, de uma espécie singular de inseto hematófago, um "barbeiro" diferente dos habituais transmissores da doença de Chagas. A Universidade poderia financiar a estada e a viagem no país, mas não o transporte até lá. Insurgiu-se o Prof. Fonseca, membro do Conselho Deliberativo do CNPq, e me vi obrigado, atendendo aos desejos dos Professores Costa Ribeiro e Arthur Moses, a solicitar ao Chefe de Polícia de então, General Cyro Rezende, uma sindicância a respeito, que me foi favorável, tendo o referido militar firmado declaração explícita. A passagem foi concedida, e o trabalho de pesquisa científica, realizado e publicado, contrariando assim o Prof. Olympio da Fonseca.

Já anteriormente, ele próprio se convertera em meu inimigo pessoal, quando me vi obrigado, como perito científico do Professor Waldemiro Potsch, 
antigo catedrático do Colégio Pedro II, em ação que este moveu contra o Prof. Cândido de MelloLeitão, a mostrar sua parcialidade na questão quando, nomeado pelo Juiz do pleito, processara perícia parcial. Referindo-se a perícia a matérias de natureza científica e envolvendo conceitos de apreciação sobre livros didáticos, foi grande, na época, a repercussão do que estava acontecendo. Existem vários livros publicados, como também depoimentos de professores e cientistas em cartas publicadas; cabe aqui transcrever um depoimento, $\mathrm{o}$ do Prof. Zeferino Vaz, atual Reitor da Universidade de Campinas, da qual foi fundador e grande propulsor, como o fora anteriormente da Faculdade de Medicina de Ribeirão Preto.

O trecho da carta do Prof. Zeferino Vaz ao Prof. Waldemiro Potsch é o seguinte:

Foi pois com a mais profunda tristeza que soube, através da contestação de Herman Lent, do laudo do Prof. Olympio da Fonseca Filho. A tristeza derivou, não de ele não ter reconhecido que os poucos erros encontrados em seu compêndio de Zoologia podem ser apontados em qualquer bom livro, mas sim pelas citações intencional mente deturpadas que dele fez, em laudo pericial, um perito que, por ser do juiz e, por ser um professor, carregava sobre os ombros a dupla personalidade de julgador e de catedrático da Universidade do Brasil.

A má-fé com que Olympio da Fonseca Filho transcreveu, modificando-os, textos de seu compêndio de Zoologia, 
tornando errados conceitos certos, para depois demonstrar os erros, é coisa cujo entendimento está acima de minhas forças.

Creia que seria para mim motivo de satisfação que alguém me desse explicação decente dessa atitude do Prof. Olympio da Fonseca Filho.

A indicação do Prof. Olympio da Fonseca Filho para presidente da Comissão de Inquérito no Instituto Oswaldo Cruz constituiu surpresa generalizada, pois se achava ele praticamente incompatibilizado com o corpo científico do Instituto, tais os desmandos que praticara durante sua curta direção naquela instituição. Os cientistas chegaram, na ocasião, a solicitar ao Presidente Getúlio Vargas a demissão do diretor, encaminhando representação pormenorizada que atingiu afinal o objetivo a que se propunha, a substituição do mau diretor.

Considera-se que a realização do IPM paralelo, chefiado pelo General Falcão, representou a forma pela qual se tornou possível forçar a isenção do presidente da comissão civil de inquérito. E isso se comprova pelo fato surpreendente de que a comissão que presidia deu ciência dos autos do processo, embora inconclusos, a cada inquirido, após terminados os depoimentos, isto é, os autos de fls. 1 a 254. E uma ficha escrita do próprio punho do Prof. O. da Fonseca indicava os depoimentos com acusações individuais sobre os quais desejava esclarecimentos. Sobre isso considero sugestivo 
reproduzir aqui duas amostras dessas "acusações" e a resposta que fiz incluir nos autos:

A) - De Gilberto de Azevedo Teixeira - Relaciona a "existência de grupamento de tendências esquerdistas, que assumiu o controle do Instituto desde a direção do Prof. Amilcar Vianna Martins", com a dificuldade de "admissão ao IOC de técnicos que não comungassem com suas ideias esquerdistas". E me inclui entre seus chefes, sem apresentar documentos, mas contradizendo-se a seguir, quando declara "que não sabe informar se seus componentes procuravam aliciar adeptos para o credo comunista, bem como não sabe informar se exerciam atividades subversivas".

Não diz, entretanto, que ele próprio foi reprovado no último concurso para Biologista realizado pelo DASP, como não diz também ter sido efetivado como Biologista, apesar de reprovado no concurso para esta mesma carreira. E na banca que o examinou e reprovou não existia nenhum signatário do malfadado telegrama, que vem caracterizando o "grupo esquerdista". A banca era presidida pelo Dr. Tito Cavalcanti e constituída pelos Drs. Oswino Penna e Madureira Pará.

De que forma ajustar essa banca e a reprovação do depoente Gilberto de Azevedo Teixeira com a declaração dele próprio, que está nos autos, 
de que a "realização do último concurso para Biologista do M.S." teve a finalidade principal de afastar elementos, por esse grupo considerados indesejáveis? É verdade que o Dr. Tito Cavalcanti foi apontado pelo depoente como também fazendo parte do grupo, porém ele era o presidente geral do concurso, que tinha examinadores constituindo bancas diferentes em cada especialidade; a que reprovou o depoente, considerando-o incapaz de fazer parte do quadro de cientistas do IOC, tendo sido constituída pelos Profs. Oswino Penna e Madureira Pará.

Aliás, como exemplo de inconsistência desse tipo de "acusação" está a aprovação, nesse mesmo concurso, de mais de uma dezena de candidatos. Serão todos esquerdistas?

B) - De Antonio Augusto Xavier - A única referência que este ex-diretor do Instituto faz ao meu nome, e que muito me honra e não me espanta, é a de que fui "conselheiro" do diretor na administração do Dr. Tito Cavalcanti, quando fui Chefe da Divisão de Zoologia e, como tal, tomei parte nas reuniões dos chefes das várias Divisões.

De que forma pensa aquele ex-diretor do Instituto, que o foi este depoente, se deva dirigir essa instituição? Sem assessores? Quais são os naturais conselheiros de um diretor? Seus 
auxiliares imediatos, os Chefes de Divisão. Quais eram esses Chefes? Na Divisão de Microbiologia, o Dr. Arêa Leão; na de Virologia, o Dr. Henrique Penna; na de Higiene, o Dr. J. G. Lacorte; na de Endemias, o Dr. Julio Muniz; na de Patologia, o Dr. Walter Cruz; na de Química, o Dr. Gilberto Villela; no Hospital, o Dr. Genard Nóbrega; e na de Zoologia, o Dr. Herman Lent. Mas só este último era "conselheiro", afirmação que não resiste a um piparote, como se fosse possível a um diretor do IOC ser tão onisciente e tão onipresente que dispensasse os "conselhos" de todos os seus auxiliares imediatos para atender somente aos de um, exatamente o mais moço.

Afirmação leviana como tantas outras que existem no depoimento do Dr. A. A. Xavier, idênticas às mesmas leviandades que escreve em seus trabalhos "científicos", como aquela em que, utilizando rãs, introduziu um cateter de borracha "pela gloteatravés do esôfago até a cavidade gástrica" (O Hospital, vol. 43 , nº 2, pág. 238, fev. 1953), barbaridade que meus alunos de 15 anos de idade jamais diriam.

Nesses autos nada vi que possam configurar-me como tendo praticado atos contra a segurança nacional, contra o regime democrático ou de improbidade administrativa. Ou são referências generalizadas, mais ou menos veladas, ou são detalhes que se ligam a minhas atividades 
administrativas, a princípio como Chefe da Seção de Entomologia e depois como Chefe da Divisão de Zoologia.

Aliás, é o que assevera, em relação a vários colegas também, o Prof. Olympio da Fonseca Filho em sua entrevista recente ao Jornal do Brasil (19/02/1978), ao dizer que a sua comissão apurou o óbvio, isto é, que o Instituto não era o foco de comunismo propalado; que não se comprovara a ocorrência, em qualquer tempo, de atos subversivos ou de reuniões com esta finalidade ou atos contra a probidade administrativa; que não houve sugestões de punição de ninguém.

Confrontemos agora essas declarações do presidente da comissão de Inquérito realizada em 1964, com o que escreveu em carta dirigida ao Jornal do Brasil e publicada na edição de 05/10/1974 pelo Dr. Francisco de Paula da Rocha Lagoa:

Ao assumirmos a direção do Instituto Oswaldo Cruz, em junho de 1964, já havia sido ultimado um IPM na Instituição, instaurado logo após a Revolução de março de 1964, o qual culminou com proposta ao Conselho de Segurança Nacional para aposentar pelo AI-5 alguns pesquisadores, o que foi concretizado por decreto do Exmo. Sr. Presidente Médici.

Ao responder a essa inverdade, que agora o próprio Presidente da Comissão de Inquérito faz ressaltar, já havia eu mostrado (Jornal do Brasil, 03/11/1974) 
que não poderia aquela comissão ter solicitado ou proposto ao Conselho Nacional de Segurança a aposentadoria de alguns pesquisadores pelo Ato-5, que em 1964 não existia.

A responsabilidade, à qual o Dr. Rocha Lagoa deseja fugir está, dessa forma, bem demonstrada.

A verdade é que nunca houve, em Manguinhos, grupo algum com as características que o Prof. O. da Fonseca, na aludida entrevista recente, quis dar; o grupo só se constituiu, forçado, após a cassação feita, em grupo. Senão, vejamos: dos 18 signatários do famigerado telegrama de 1946, 5 não pertenciam ao Instituto Oswaldo Cruz, e, dos 13 restantes, 4 não foram cassados (um por ter falecido, e os outros, por quê?). Aos 9 signatários restantes, Rocha Lagoa adicionou, na hora da cassação, um outro nome, enquanto anteriormente havia apontado, como merecedores de punição, 4 grupos de 4 , isto é, 16. Onde, então, o grupo?

O que havia, isto sim, em Manguinhos, era um fosso aberto entre os que trabalhavam e necessitavam vencer todas as dificuldades e os que nada faziam e obtinham os postos e as facilidades. Os que mais ativamente lutavam, reclamando seus direitos, propondo saídas para o progresso da instituição, representando às 
entidades governamentais, manifestando ideias e propósitos, foram acoimados de "comunistas", pois esse apodo sempre foi caminho fácil para liquidação de desafetos ou remoção de obstáculos a objetivos inconfessáveis. Enfrentar iniquidades e incompreensões é perigoso, quando os contendores não se pejam em adotar os métodos macarthistas que tanto mal já provocaram em diversas partes do mundo. Pleitear, por exemplo, melhores condições de trabalho; tornar evidente o papel da pesquisa e da tecnologia para as atividades sociais do país; sugerir medidas que levem à criação de um Ministério para a Ciência e a Tecnologia; apoiar e prestigiar o pesquisador individualmente, como forma de protegê-lo da ação coercitiva de eventuais maus diretores; apoiar a liberdade intelectual e de pesquisa e os direitos dos pesquisadores a dispor de seus trabalhos e a publicá-los sob a responsabilidade de sua própria assinatura; defender os recursos necessários ao trabalho quando os incentivos das próprias instituições não sejam suficientes; defender os direitos de comparecimento a congressos e reuniões científicas; lutar pela necessidade e oportunidade de visitar locais de trabalho mais avançados e pelas bolsas de estudo para os iniciantes, fazem parte de um contexto que ao tempo do Instituto Oswaldo 
Cruz entregue à direção de F. P. Rocha Lagoa permitiram a exacerbação de uma faceta daquilo que se denomina anticomunismo. Isto porque, se é difícil contrariar os pontos de vista enumerados, torna-se muito fácil neutralizá-los, fazendo saltar o apodo habitual do dedo-duro. 


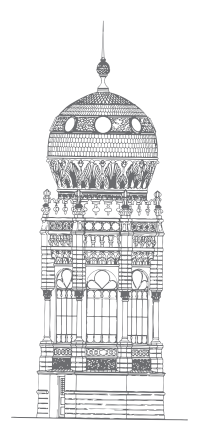

O

massacre de Manguinhos, para mim, não se refere tanto ao que aconteceu com os dez cientistas cassados. Atingiu mais o Instituto Oswaldo Cruz, atingiu profundamente o país. A destruição não se limitou ao afastamento daquelas pessoas; outras foram dali deslocadas e deixaram de contribuir para o desenvolvimento da ciência: Laerte Manhães de Andrade, microbiologista; Jorge Guimarães, patologista; Mario Vianna Dias e Charles Esberard, fisiologistas, foram transferidos por Lagoa para outros locais onde não puderam prosseguir seus trabalhos. E muitos se aposentaram, quando possível, enojados.

Demitido do cargo de Ministro, um tratamento raro nos Governos da Revolução de 1964, Rocha Lagoa teve, contudo, a proteção de não se deixar divulgar os motivos pelos quais foi obrigado a deixar o cargo que tanto ambicionou. Mas o semanário Politika, de 26/02/1972, desta forma resumiu o evento: 
Eis aí. Os cientistas tinham dito que ele era um burocrata incompetente. A demissão agora assinada pelo presidente da República veio provar que, de fato, o doutor Lagoa não era tão incompetente assim. Ao menos em aplicação de recursos orçamentários...

O Tribunal de Contas da União, segundo relata o Estado de São Paulo, havia encaminhado à presidência da República um dossiê que forçou a saída do ministro.

Em seu discurso de 20 de outubro de 1970 (Jornal do Brasil, 21/10/1970), ao receber o título de Doutor Honoris Causa da Universidade Federal do Rio Grande do Sul, o Presidente Garrastazu Médici afirmou-se paladino da justiça, em termos claros e definitivos: "Quem quer a ordem há de querer também a justiça, que constitui, segundo expressão que já se tornou clássica, o maior interesse do homem sobre a terra".

Para, em seguida, definirem período claro e curto o sentimento interior do injustiçado, que amarga e corrói e aumenta e sobreleva a qualquer outro sentimento, quando impedida de vir à tona a razão motivadora:

Plena razão assiste a quem disse que o homem suporta com estoicismo os sofrimentos que resultam de causas naturais, mas não pode conformar-se, no intimo do coração, com os males provenientes da injustiça, pois que estes são evitáveis, não fatais, decorrendo de vícios da vontade humana. 
É o que ocorre nos casos em que o poder da Revolução se exerceu, com base em atos institucionais, sobre homens de ciência e de cultura, aposentandoos através de atos indefensáveis e irrecorríveis e impedindo-lhes de exercer as mesmas atividades de trabalho através das quais se tornaram conhecidos e úteis à coletividade.

Em abril de 1970, por exemplo, o Presidente Médici atingiu, dessa maneira, 10 cientistas do Instituto Oswaldo Cruz, cujas vidas estiveram vinculadas àquela instituição por mais de 30 anos, onde produziam trabalho científico e ensino especializado de relevante valor. Sem considerar a injustiça flagrante do ato que os atingiu, reconhecida como decorrente da vingança de ex-diretor inconformado pela contestação de seus atos administrativos mal orientados, que os atingidos promoveram sob a responsabilidade de seus nomes e visando beneficiar e elevar os objetivos da instituição, sem considerar também a injustiça promovida contra o próprio Instituto Oswaldo Cruz, que assim teve afastado de seu quadro de pesquisadores, hoje muito reduzido, homens de elevado conceito, queremos realçar aqui a injustiça que representa impedir, praticamente, $o$ trabalho desses cientistas e o aproveitamento de seus conhecimentos, no país, já que não puderam exercer atividades remuneradas ou não em estabelecimentos de ensino ou de pesquisa, os únicos capazes de proporcionar laboratórios e bibliotecas à altura. 
O inconformismo com a injustiça, de que tão objetivamente falou o ex-Presidente Médici, é justamente o que nos leva a apontar esse tratamento que a nada leva, nada constrói, fazendo recrudescer aqueles males evitáveis, aludidos pelo Presidente, que decorrem de vícios da vontade humana.

Oito anos se passaram. E é possível, de cabeça fria, raciocinar sobre o acontecido. A esses homens de 60 anos ou mais, que realmente nunca precisaram justificar-se, e, para quem, contudo, a reparação moral não deixa de ser importante, me parece necessário prestar atenção. Eles foram mostrar sua capacidade em países distantes, na Venezuela, nos Estados Unidos, na Alemanha, na Inglaterra, na França, em Moçambique, em atividades nacionais não governamentais. Eles deixaram discípulos que isso apregoam de cabeça erguida e também receberam de alguma forma a herança da perseguição imposta. Como tantos outros, aposentados de suas cátedras e laboratórios.

Suas famílias sobreviveram ao impacto de intuito degradante ao que deles disse o líder do governo no Senado, Sr. Eurico Rezende, ao tentar responder às indagações críticas do Senador Edmundo Levi (Diário do Congresso Nacional, 28/04/1970, pp. 596-597, 604606), que solicitava os motivos de, pela primeira vez, se suspenderem direitos políticos de pessoas que não 


\section{militavam em partidos políticos. O Senador Rezende emitiu, então, o seguinte insulto:}

Respondo tranquilamente o aparte de V. Exa. O eminente representante do Amazonas reivindica a divulgação dos fatos que autorizam as punições revolucionárias. Estas incidem sobre dois tipos de ilícito: a subversão e a corrupção. Saiba, então $V$. Exa., que as suas palavras se aceitas pelo Governo revolucionário, poderiam, perfeitamente, funcionar como expressas e defendidas pelo "advogado do diabo" ou, então, por quem de boa-fé deseja uma fórmula que, ao revés de beneficiar os punidos, poderá colocá-los diante da execração da opinião pública. Melhor, melhor, para os que são assim punidos, notadamente por atos de corrupção, que aqueles fatos fiquem na solidão e no esquecimento dos arquivos, para que pelo menos as suas famílias não experimentem o impacto das decepções ou, então, das amarguras revoltadas. A solicitação que $V$. Exa. faz é inteiramente contrária aos interesses dos próprios punidos.

\section{Ao que imediatamente o Senador Josaphat Marinho retrucou:}

$O$ argumento de V.Exa., em resposta ao nobre Senador Edmundo Levi, não convence ninguém. Primeiro, porque a Imprensa publicou que vários dos atingidos manifestaram absoluta surpresa pela punição sofrida, o que está a indicar que não temem o público e o exato conhecimento dos fatos; e, segundo, porque nós, representantes do povo, não pedimos os fatos para preservar situações pessoais de possíveis culpados, mas para defender inocentes. Se alguém foi punido mediante segura apuração dos fatos, responda por suas faltas. O que não é correto, o que não é justo é que, em nome de um silêncio imposto, misturem-se prováveis culpados e inocentes, 
contando que o Governo não seja compelido a dizer, de público, as razões de seus atos. Não! Não transfira V. Exa., do Governo para os punidos, o temor do conhecimento público dos fatos.

Os fatos a punir não foram fornecidos até hoje; por um motivo simples: não existem.

Pois saiba o ainda hoje líder do Governo, Senador Eurico Rezende, que continuamos interessados nos fatos. Seus conceitos não nos levaram ao alcoolismo, aos tóxicos, ao desespero. E continuamos cobrando a comprovação dos fatos, não que precisemos de qualquer justificação. Tão somente porque sabemos quais são eles. Aí acabamos de expô-los abreviadamente para o julgamento de todos. 


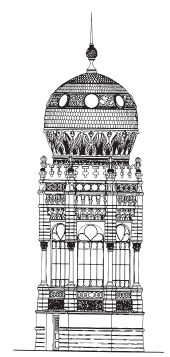




\section{Posfácio}

\section{Ciência, saúde e política no regime militar: "O Massacre de Manguinhos"}

— m agosto de 1986, a Fundação Oswaldo Cruz (Fiocruz) reintegrou em seus quadros os dez cientistas cassados e aposentados compulsoriamente pela ditadura militar (1964-1985). Este fato se revestiu de um duplo sentido: por um lado, reparar a injustiça cometida pelo regime militar, e, por outro, afirmar ao mesmo tempo o processo de redemocratização da instituição, que se iniciava na gestão de Antônio Sérgio da Silva Arouca (1985-1989).

Em pouco mais de 30 anos, a Fiocruz se transformou progressivamente em uma instituição estratégica do Estado, atuante nos campos da ciência, da tecnologia, da inovação, da educação e da produção tecnológica de serviços e insumos para a promoção da saúde da população e a efetivação da cidadania, alicerçada em uma estrutura organizacional transparente, democrática e participativa. As eleições internas para presidente e diretor de unidade e a criação de fóruns institucionais coletivos, como os conselhos deliberativos e o Congresso Interno, são exemplos de mecanismos decisórios que buscam construir consenso em bases democráticas em torno do projeto institucional. 
Foi justamente a falta de consenso a respeito do papel social da instituição, em um contexto político centralizador e autoritário, um dos principais fatores que levaram à cassação dos cientistas do Instituto Oswaldo Cruz (IOC), no episódio que ficou conhecido como "O Massacre de Manguinhos", termo cunhado por Herman Lent (1978).

Durante as três primeiras décadas de sua existência (1900-1930), o Instituto Oswaldo Cruz construiu seu papel na ciência biomédica brasileira em função de um modelo de organização de suas práticas de pesquisa e de legitimação de suas atividades na vida pública nacional que se caracterizava pela estreita relação entre a investigação científica e os interesses presentes na sociedade, sobretudo pela capacidade de identificar e responder aos problemas concretos da saúde pública brasileira (STEPAN, 1976; BENCHIMOL, 1990; SCHWARTZMAN, 2001).

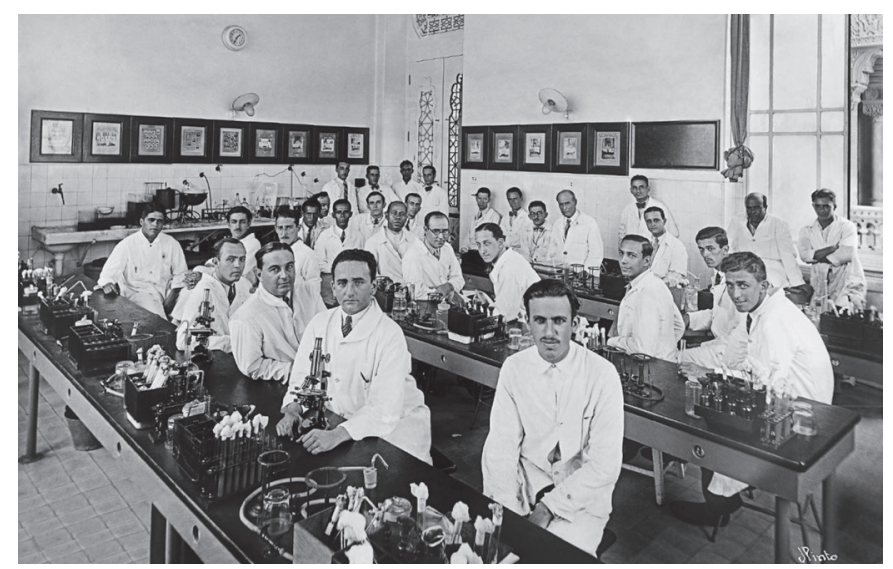

Laboratório de pesquisa do IOC, Curso de Aplicação, 1931. Foto: J. Pinto. Acervo Casa de Oswaldo Cruz. 
Essas condições começariam a se alterar a partir do governo de Getúlio Vargas. O IOC, até então vinculado à pasta da Justiça, passou, em 1930, para a jurisdição do então criado Ministério da Educação e Saúde Pública, perdendo progressivamente a centralidade que possuíra até então no âmbito da formulação e implementação de políticas e medidas sanitárias para o país. ${ }^{1}$ Este fato, aliado à degradação dos salários, à evasão de pesquisadores, à deterioração das instalações físicas e equipamentos, colocava sérios obstáculos para a reprodução do projeto institucional (AZEVEDO et al., 2002).

Uma nova mudança institucional ocorreria em 1953, quando o Instituto Oswaldo Cruz passou a vincular-se diretamente ao Ministério da Saúde, naquele momento recém-separado do Ministério da Educação. Essa reforma organizacional não implicou mudanças significativas, pois as estruturas institucionais se mantiveram as mesmas, tendo ocorrido basicamente uma separação entre os serviços que diziam respeito à área da educação e os da saúde (HAMILTON; FONSECA, 2003). Contudo, a criação do Departamento Nacional de Endemias Rurais em 1956, cujas prioridades consistiam em organizar, coordenar e executar os serviços de combate às doenças endêmicas consideradas prioritárias, indica a progressiva centralização das atividades do Ministério da Saúde (BUSS et al., 1976).

Nesse contexto, o IOC perdeu definitivamente, além de sua autonomia política, a influência sobre a política sanitária global, restringindo-se à produção 


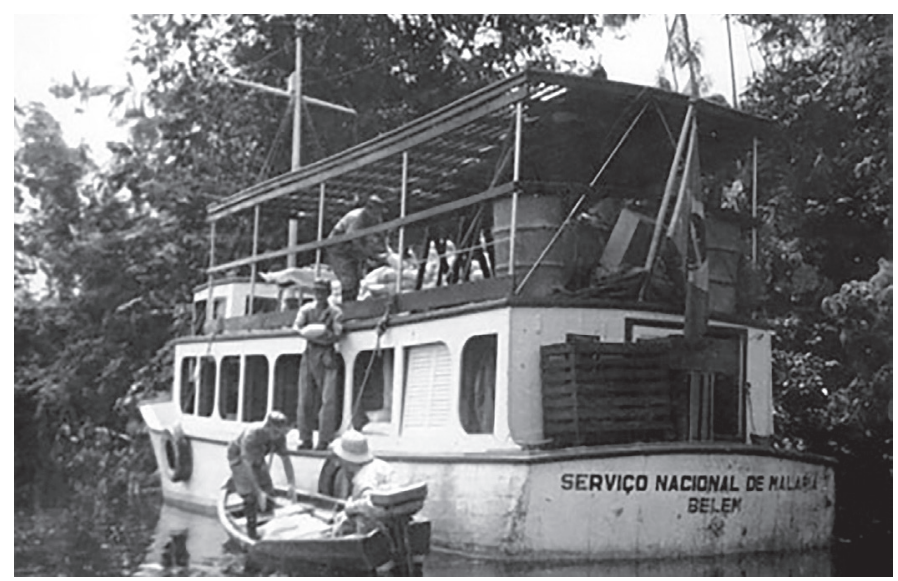

Distribuição de sal cloroquinado pelo Serviço Nacional de Malária, na Amazônia, em 1952, década em que foi criado o Departamento Nacional de Endemias Rurais (DNERu). Acervo Casa de Oswaldo Cruz.

de soros, vacinas e reagentes. A instituição tornouse um órgão fundamental ao andamento das campanhas organizadas pelo governo, dedicando seu orçamento à produção de imunobiológicos para atender às demandas crescentes do Ministério. Desde 1950, Manguinhos é o único produtor da vacina contra a febre amarela no Brasil e foi um dos principais produtores da vacina antivariólica. Esta última se intensificou a partir do lançamento da Campanha da Erradicação da Varíola no Brasil, em conjunto com a Organização Mundial da Saúde (OMS), no início da década de 1960. Contando com o apoio financeiro da Organização Pan-Americana de Saúde (Opas) e introduzindo a técnica da vacina liofilizada, o IOC, que produzia 9,522 milhões de doses em 1962, passou a produzir 42 milhões de 
doses em 1966 para serem distribuídas em todo o território nacional.

A Segunda Guerra Mundial influiu de maneira decisiva sobre o processo de institucionalização da ciência moderna, gerando um forte impacto na relação entre ciência, tecnologia e sociedade. A ciência passou a ser reconhecida como um bem nacional, um instrumento valioso para fins militares, econômicos e sociais. Afirmava-se então que a pesquisa básica, entendida como uma atividade sem fins práticos, constituía o alicerce do desenvolvimento de tecnologias e inovações. Essa perspectiva, que seria chamada de modelo linear de inovação, contribuiu para o aumento do prestígio público dos cientistas e os lançou em um intenso ativismo político em prol do desenvolvimento da ciência (AZEVEDO et al., 2002).

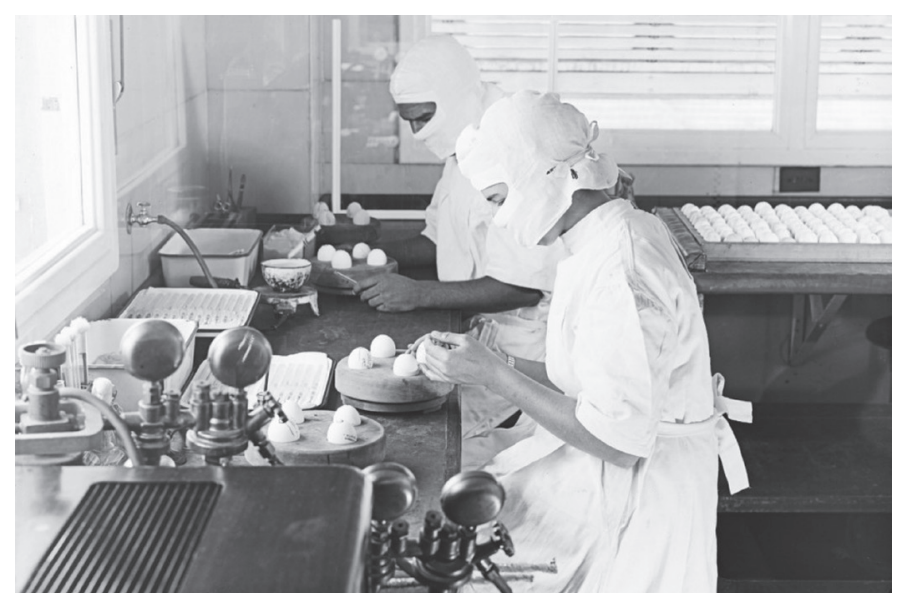

Laboratório do IOC, produção da vacina de febre amarela na primeira metade do século XX. Acervo Casa de Oswaldo Cruz. 
Na esteira dessas transformações foi fundada, em 1948, a Sociedade Brasileira para o Progresso da Ciência (SBPC), com vistas a organizar os interesses da comunidade científica nacional, a qual passou a pleitear a participação dos cientistas, junto ao governo, e a organização da atividade científica em moldes profissionais, o que requeria uma série de condições a serem asseguradas por ele, entre elas, garantir: autonomia e financiamento para a pesquisa; estabelecimento do tempo integral; melhoria salarial; e a criação de uma carreira de pesquisa nas universidades e nos institutos públicos.

Paralelamente à mudança nas relações entre o IOC e o campo da saúde pública, ocorreu uma transformação na dinâmica de institucionalização da atividade científica, que resultou em um crescente processo de profissionalização da ciência no país, cujo marco fundamental é a criação do Conselho Nacional de Pesquisa (CNPq), em 1951. O Estado firmava-se como patrocinador direto da pesquisa, por meio de bolsas e auxílios financeiros, orientado pela necessidade de equiparar $o$ Brasil às nações desenvolvidas, garantindo a participação da comunidade científica na definição e implementação da política científica (MOREL, 1979).

Vários laboratórios do Instituto Oswaldo Cruz passaram a receber seu auxílio, principalmente as divisões de Fisiologia, Entomologia e Anatomia Patológica. Em face da falta de recursos, a 
pesquisa científica se manteve graças ao aporte de financiamentos externos como os do próprio $\mathrm{CNPq}$ e da Fundação Ford, que sustentavam, por exemplo, o produtivo laboratório de Hematologia conduzido por Walter Oswaldo Cruz.

A crença de que a aplicação social do conhecimento científico seria uma consequência de investimentos em pesquisa básica, a longo prazo, teve o impacto de reorientar a agenda de pesquisa do IOC a partir dos anos de 1950. Nas gestões de Francisco da Silva Laranja Filho (1954-1955), Amilcar Vianna Martins (1958-1960), Tito Arcoverde Cavalcanti (1960-1961) e Joaquim Travassos da Rosa (1962-1964) dispõese de um órgão colegiado de gestão da instituição, o Conselho Deliberativo, composto pelos chefes de divisões e de uma orientação que passaria a dar relevância ao desenvolvimento dos campos básicos do conhecimento biomédico e biológico, e não somente às investigações aplicadas ao campo da saúde pública.

Nesse aspecto, cabe ressaltar a crescente proeminência alcançada pelos grupos atuantes nos campos da fisiologia e da zoologia, liderados respectivamente por Miguel Ozório de Almeida e Lauro Travassos, cujos trabalhos voltavamse fundamentalmente para aspectos básicos do conhecimento biomédico e biológico. Era justamente nesses dois campos do conhecimento que atuava, desde os anos de 1930 e 1940, a maioria dos cientistas que estaria na lista das cassações em $1970 .^{2}$ 
Outro aspecto relevante do movimento pelo desenvolvimento da ciência foi a mobilização em torno da criação do Ministério da Ciência, originada na SBPC no final da década de 1950. Os pontos fundamentais da proposta eram garantir à comunidade científica um espaço de participação nas decisões a respeito de um projeto científico definido nacionalmente e implementar uma política visando à autonomia e à liberdade científica para fazer face aos critérios utilitários adotados por órgãos governamentais. Só assim seria resgatado o papel que a ciência cumprira no processo de desenvolvimento brasileiro.

Vários pesquisadores do IOC estavam articulados a esse movimento, principalmente Herman Lent,
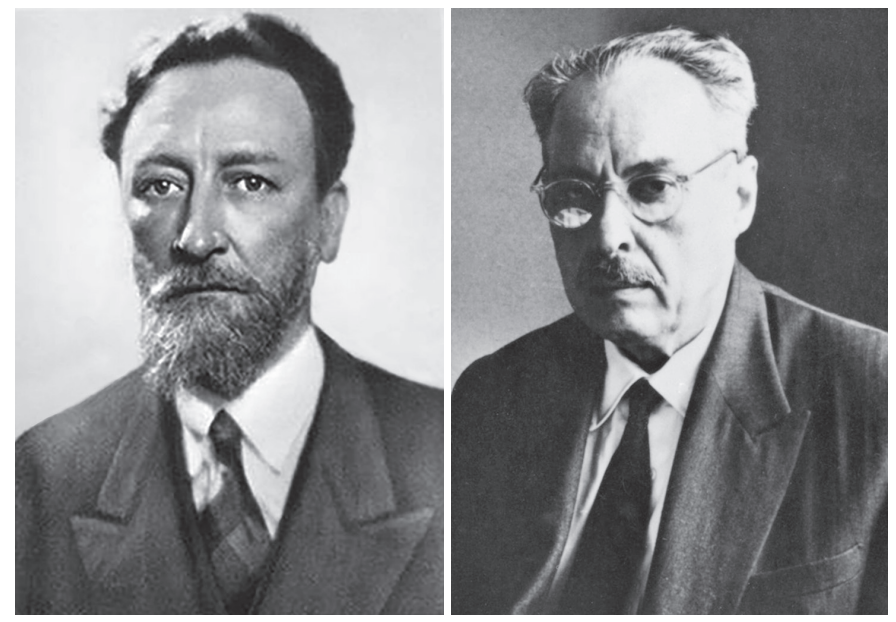

Pesquisadores Miguel Ozório de Almeida e Lauro Travassos, s.d. Acervo Casa de Oswaldo Cruz. 
Haity Moussatché, Walter Oswaldo Cruz e Tito Cavalcanti. Segundo esse grupo, a transferência do Instituto Oswaldo Cruz para a esfera do novo ministério o transformaria em uma instituição de investigação básica, libertando a comunidade científica do peso de ter de trabalhar em assuntos exclusivamente de interesse médico e da responsabilidade pela produção de soros e vacinas, que pesavam na balança na hora da distribuição de recursos (LENT, 1978).

Apesar da consonância desse discurso com o clima desenvolvimentista do governo de Juscelino Kubitschek (1956-1961), essas reivindicações não chegariam a se efetivar. Sua expressão mais concreta seria a organização da Universidade de Brasília, planejada por esse grupo. Alguns dos cientistas mobilizados na implementação dessa instituição estariam, anos depois, na lista dos cassados e aposentados pelo regime militar.

No outro lado dessa dicotomia, encontramos a orientação de que o IOC deveria manter-se essencialmente como um instituto de pesquisa aplicada. Esta corrente veiculava a ideia de que, diante dos escassos recursos de que dispunha a instituição, deveriam ser priorizadas a produção de imunobiológicos e a pesquisa voltada para doenças que atingiam a população. Nessa perspectiva, uma instituição associada às políticas de saúde pública como o Instituto Oswaldo Cruz deveria reforçar os setores que correspondiam às demandas do Ministério da Saúde. A pesquisa sem preocupação 
com a aplicabilidade do conhecimento ocuparia, portanto, um segundo plano.

Foram essas transformações que colocaram em questão o perfil institucional do IOC, gerando um estado de polarização e tensão interna decorrentes da falta de consenso a respeito do seu perfil (BRITTO et al., 1988). Os cientistas do IOC, e suas bases de apoio social, participaram dessa polêmica ativamente, cada qual representando uma identidade profissional específica que tentava impor as suas concepções e interesses científicos políticos.

No dia $1^{\circ}$ de abril de 1964, em meio à grave crise política, o presidente João Goulart (1961-1964) foi deposto pelo golpe militar, que instituiu um regime que alteraria o modelo político e econômico vigente e firmaria as bases para a articulação de uma nova aliança no interior do Estado, na qual as Forças Armadas se constituíram como fração hegemônica. A ascensão do marechal Castelo Branco à Presidência da República caracterizouse por dois fenômenos complementares. Por um lado, procurou-se a retomada do desenvolvimento econômico, reservando ao capital estrangeiro um papel preponderante. Por outro, sob o lema da "segurança nacional", a ordem institucional foi quebrada sob o argumento da necessidade de combater o comunismo (MOTTA, 2000).

Inaugurando uma série de medidas arbitrárias, o presidente decretou o Ato Institucional no 1 (AI-1), que cassou os direitos de centenas de militares e 
políticos de oposição. Foram instaurados inquéritos policiais militares (IPMs) que atingiram a maioria das instituições da esfera pública.

Esse contexto político inaugurou no Instituto Oswaldo Cruz uma fase crítica da sua história, marcada pela polarização dos conflitos e pela intervenção direta dos mecanismos repressivos que caracterizaram a ditadura militar.

Entre 1964 e 1970, diferentes órgãos de segurança e informação acompanharam as atividades dos cientistas do Instituto Oswaldo Cruz. O primeiro inquérito militar na instituição iniciou-se sob a direção do general Aluizio Falcão para apurar atos de subversão e corrupção entre seus funcionários. Paralelamente, um inquérito civil para tratar de assuntos administrativos foi instaurado pelo Ministério da Saúde. Uma terceira investigação foi instaurada em 1966. Sob acusação direta de Rocha Lagoa, então diretor de Manguinhos, foram intimados, pelo serviço de segurança do Ministério da Saúde, os cientistas que contavam com maiores financiamentos para suas pesquisas, obtidos de instituições privadas e governamentais.

Após a conclusão dos inquéritos, que nada provaram contra os cientistas na esfera civil e militar, o regime manteve o controle das atividades consideradas subversivas ocorridas no IOC, como mostram documentos secretos produzidos pelos diferentes órgãos de informação. ${ }^{3}$ 
O ministro da Saúde Raimundo de Britto (19651967), político oriundo da UDN e ex-secretário do governo Carlos Lacerda, deixou clara sua intenção de adaptar as instituições às novas condições impostas pelo regime militar, afirmando: "As ideias exóticas que em Manguinhos foram infiltradas serão banidas definitivamente [...]. Manguinhos de amanhã será uma colmeia de trabalho e não um foco de ideias subversivas". ${ }^{4}$

No dia 23 de junho, Raimundo de Britto nomeou o médico Francisco de Paula da Rocha Lagoa para chefiar o Instituto Oswaldo Cruz. Suas credenciais para ocupar o cargo, além de um fervoroso anticomunismo, consistiam na realização do curso da Escola Superior de Guerra (ESG) em 1963 no apoio do Arcebispo do Rio de Janeiro, D. Jaime Câmara, e no vínculo familiar com políticos da UDN.

No seu discurso de posse, Rocha Lagoa, funcionário de Manguinhos desde a década de 1940, estabeleceria suas ligações com o poder político militar, assumindo o papel de representante de seus ideais dentro da instituição: "Será sob a égide da família, da ciência, da cruz e dos ideais de desenvolvimento, bem-estar e segurança do Brasil que pretendemos encetar esta jornada e moldar nossas ações em prol da maior grandeza de nossa pátria" ${ }^{5}$

Procurando adequar-se às diretrizes gerais do Ministério da Saúde, o novo diretor criticava 
a desorganização dos trabalhos das gestões anteriores e estabelecia um programa de atividades que valorizava o estudo de problemas de patologia nacional e o incremento da produção de soros e vacinas. Todos os funcionários em cargos de chefia foram substituídos por aqueles que se adequassem melhor à nova orientação e o Conselho Deliberativo foi desativado. Assim, o grupo de pesquisadores que se mobilizava em prol de uma maior participação na definição de uma política científica nacional, e que até então vinha ocupando importantes cargos dentro da instituição perdeu espaço dentro do IOC.

A direção do IOC ainda enviou ofícios a entidades internacionais e universidades pedindo que os auxílios financeiros passassem

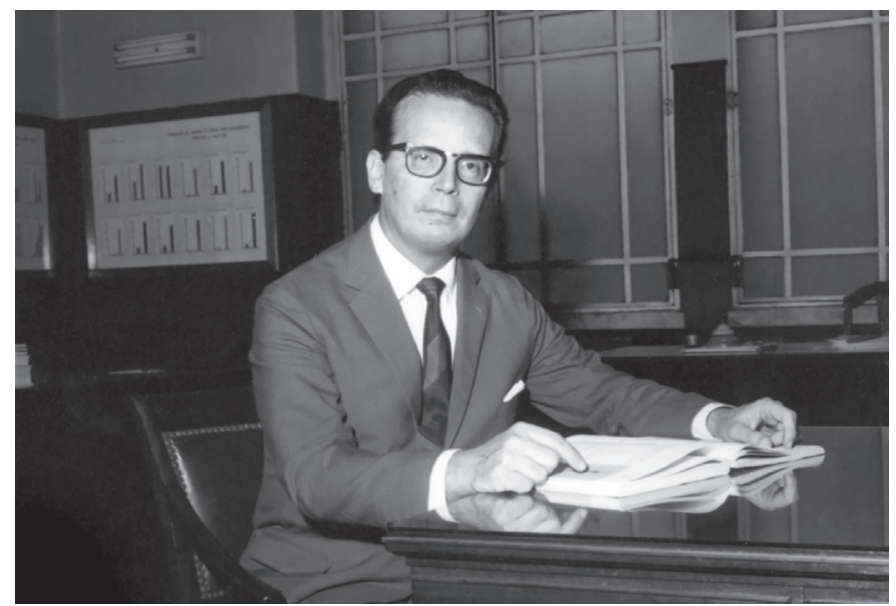

Dr. Francisco de Paula da Rocha Lagoa no interior do Castelo Mourisco, s.d.

Acervo Casa de Oswaldo Cruz. 
pelo seu crivo ao invés de seguirem diretamente para os pesquisadores beneficiados. Com isto, a direção poderia alocar recursos para os setores de seu interesse, principalmente para as divisões de microbiologia e virologia, que tiveram um aumento considerável no número de doses de vacinas e soros produzidos. Algumas instituições, porém, não aceitaram a pressão do IOC. A Fundação Ford, por exemplo, que destinaria, em 1964, 40 mil dólares para financiar principalmente a seção de hematologia, suspendeu seu auxílio.

Além de dificultar a captação de recursos externos, a centralização administrativa permitia que a direção destinasse as verbas para as áreas consideradas prioritárias, relegando outros setores a um segundo plano. Rocha Lagoa tinha, como diretor do IOC, assento garantido no Conselho Nacional de Pesquisa. Lá, ele também exerceu pressão para que os auxílios concedidos a Herman Lent e Haity Moussatché não se renovassem, sob a alegação de que desejava estabelecer trabalhos em outras linhas; consequentemente, o $\mathrm{CNPq}$ acabou por não renovar as bolsas.

Por meio da imprensa e de contatos com altos funcionários do governo, o grupo de oposição continuava a combater a transformação do Instituto Oswaldo Cruz no que eles consideravam ser apenas uma fábrica de vacinas, reiterando a necessidade de criação de um Ministério da Ciência. Haity Moussatché concedeu, na época, uma entrevista que lhe valeu uma interpelação 
da direção e, posteriormente, uma pena de repreensão constante no ofício $n^{\circ} 26$, de 1965, do IOC. ${ }^{6}$ O Jornal do Brasil de 6 de janeiro informava: "Haity Moussatché denuncia a Raimundo de Britto: 'A política dominante no Instituto tende a transformá-lo numa autêntica farmácia com sérios prejuízos ao setor de pesquisa científica'".

No início de 1965, os cientistas conseguiram uma audiência com o ministro da Saúde Raimundo de Britto para denunciar a transformação do IOC em um órgão de solução de problemas sanitários imediatos em detrimento das pesquisas. Eles propuseram a criação de um instituto de saúde pública que se encarregasse da produção de insumos e dos estudos nosológicos. O ministro manteve seu apoio à direção de Manguinhos, afirmando: "Vêm sendo feitas, nestes últimos dias, insistentes acusações à atual direção do Instituto Oswaldo Cruz, o que está a exigir esclarecimento deste Gabinete, tal a inconsistência das afirmações veiculadas". ${ }^{7}$

No plano externo, o grupo intensificava sua mobilização a favor da criação do Ministério da Ciência, projeto mais afinado com suas necessidades, conforme Herman Lent: "A definição que nós víamos como mais palpável era a passagem para o Ministério da Ciência [...] Era uma posição pública assumida claramente, considerando que era a única maneira de defender a instituição que vinha caindo cada vez mais" (LENT, 1982). 
Em junho de 1965, cientistas representando várias instituições de pesquisa, entre eles Walter Oswaldo Cruz, Haity Moussatché, Tito Cavalcanti e Herman Lent pelo IOC, participam de uma audiência com o Ministro do Planejamento, Roberto Campos, para expor a ideia do Ministério da Ciência. Tito Cavalcanti relembra o encontro: "Arthur Moses, que era presidente da $A B C$ [Academia Brasileira de Ciências], resolveu convocar um grupo de pesquisadores para apresentar a Roberto Campos, que era Ministro do Planejamento, nossa ideia de Ministério da Ciência [...] Fiz a apresentação e a entreguei por escrito a Roberto Campos. No fim ele só fez a afirmação de que os institutos devem ser órgãos de execução; órgãos de pesquisa devem ser só as universidades (Cavalcanti, 1985)".

De antemão, o ministro condenava a ideia do Ministério da Ciência, indicando o que futuramente procuraria se aplicar com a Reforma Universitária de 1968, na qual o ensino e a pesquisa apareceriam dissociados dos institutos públicos e ligados às universidades.

De fato, a proposta de criação do Ministério da Ciência ${ }^{8}$ não angariou apoio político, e, após 1964, os cientistas que a defendiam foram acusados de serem subversivos e de conspirarem contra o Estado (SANTOS, 2016). A tentativa de vinculação a uma nova secretaria foi encarada pela direção do Instituto como atitude de insubordinação ao Ministério da Saúde, passível de severas punições, como demonstra um documento elaborado por Rocha Lagoa, no qual sugere a remoção dos "notórios 
comunistas de alta periculosidade" sob o pretexto de "resguardar o bom nome da instituição, pois a campanha difamatória em curso pela imprensa e pelo rádio fere diretrizes governamentais básicas" 9 .

O governo optaria por desenvolver uma política de tecnologia de grande porte, tendo como base de sustentação as Forças Armadas e as grandes empresas multinacionais, através de acordos de importação de know-how e equipamentos. A autonomia de operações e o controle de recursos estratégicos definiram a energia nuclear como área prioritária de investimentos, seguida dos setores de comunicações, produção de armamentos e computadores, todos concentrados pelo Estado (SCHWARTZMAN, 1981).

No Programa Estratégico de Desenvolvimento (1968-1970), acentuou-se o importante papel da educação para o progresso tecnológico. A Reforma Universitária de 1968 se caracterizaria por medidas técnicasvisandotornarosistemadeensinosuperiormais eficiente. Simultaneamente, foram implementadas medidas de caráter punitivo, restringindo os aspectos políticos e críticos da universidade. $\mathrm{O}$ governo incentivava o desenvolvimento científico e tecnológico, mas afastava dos centros de decisão os elementos mais qualificados da comunidade científica, desarticulando os setores mais críticos e contrariando os ideais de autonomia, liberdade e participação.

Após 1968, várias universidades e institutos, entre eles a Universidade de São Paulo (USP), a 
Universidade do Estado do Rio de Janeiro (Uerj), a Universidade Federal de Minas Gerais (UFMG),

o Centro Brasileiro de Pesquisas Físicas (CBPF), a Universidade de Brasília (UnB), teriam professores e pesquisadores cassados ou aposentados por atos institucionais, reflexo do clima político da época, marcado pelo endurecimento do regime militar, que impôs o Ato Institucional n ${ }^{\circ} 5$ (AI-5). Este conferia plenos poderes ao Executivo, prevendo a suspensão dos direitos políticos de qualquer cidadão, a censura prévia à imprensa e o redimensionamento do Serviço Nacional de Informações (SNI), medidas necessárias à atuação das Forças Armadas envolvidas com a repressão.

A ascensão do general Médici à Presidência da República em outubro de 1969, inaugurando os anos de maior repressão e controle do regime militar, e a nomeação de Rocha Lagoa para o Ministério da Saúde configurariam o quadro para os acontecimentos do dia $1^{\circ}$ de abril de 1970 . No dia seguinte, o Diário Oficial publicava o decreto, baseado no AI-5, que suspendia os direitos políticos por dez anos de Haity Moussatché, Herman Lent, Moacyr Vaz de Andrade, Augusto Cid Mello Perissé, Hugo de Souza Lopes, Sebastião José de Oliveira, Fernando Braga Ubatuba e Tito Cavalcanti. Como a punição não implicava o afastamento de Manguinhos, um novo decreto aposentava e elevava para dez a lista de cientistas atingidos, incluindo os nomes de Domingos Arthur Machado Filho e Masao Goto. 
O panorama político repressivo era avesso a fórmulas integradoras. O conflito de posições no IOC encerrouse quando o grupo de oposição à diretoria foi excluído dos seus quadros. As medidas repressivas foram o recurso utilizado para alijar os cientistas cujas vozes eram dissonantes às orientações do regime militar, sob a acusação difusa de comunismo. Os cientistas portadores de um discurso alternativo de política institucional foram sumariamente afastados do Instituto Oswaldo Cruz em um período que se caracterizou pelo fechamento dos canais de participação, pela centralização do poder nas Forças Armadas e pela eliminação dos setores críticos da sociedade civil (HAMILTON, 1989).

O saldo desse processo significou, na verdade, a derrota das aspirações de ambos os grupos, atingindo tanto a produção científica quanto imunobiológica, além de ter provocado uma séria crise de paralisia institucional que teve reflexos em todos os setores do Instituto Oswaldo Cruz. Incorporado à Fundação Instituto Oswaldo Cruz, criada em 1970 e denominada Fundação Oswaldo Cruz em 1974, o IOC se defrontou até meados da década de 1980 com linhas de pesquisas interrompidas, formação de jovens pesquisadores paralisadas, laboratórios fechados, falta de pessoal, acordos de cooperação suspensos e importantes coleções científicas sob sério risco de destruição.

Wanda Hamilton

Pesquisadora da Casa de Oswaldo Cruz/Fiocruz 


\section{Notas}

1 A formulação e implementação de políticas sanitárias passaria, progressivamente, a ser exercida por profissionais com formação e especialização em saúde pública. A esse respeito, ver Fonseca (2007).

2 Na divisão de Zoologia estavam lotados Herman Lent, Hugo de Souza Lopes, Domingos Arthur Machado e Sebastião José de Oliveira; na divisão de Fisiologia Haity Moussatché, Tito Arcoverde Cavalcanti e Fernando Braga Ubatuba. Masao Goto e Moacyr Vaz de Andrade desempenhavam suas atividades no laboratório de Micologia, chefiado até 1964 por Antônio Arêa-Leão; e Augusto Cid de Mello Perissé pertencia ao laboratório de química.

3 Para uma análise mais detalhada dos processos gerados pelos órgãos de segurança, ver Santos (2016).

4 Correio da Manhã, 24/04/1965.

5 Tribuna Médica, 26/06/1964.

6 Casa de Oswaldo Cruz. Fundo Instituto Oswaldo Cruz, Seção Direção, Dossiê 005 (Ordens de Serviço), Livro 00263, Portaria n². (BR RJ COC 02-05-005).

7 Correio da Manhã, 30/01/1965

8 O Ministério da Ciência e da Tecnologia foi criado durante o governo de José Sarney (1985-1990) pelo Decreto no 91.146 de 15 de março de 1985.

9 Arquivo Nacional. Serviço Nacional de Informação - SNI (Agência Rio de Janeiro). Informe Especial, de $1^{\circ}$ de dezembro de 1967, do diretor do Instituto Oswaldo Cruz ao ministro da Saúde. (ARJ-ACE-5216-69). 


\section{Referências bibliográficas}

AZEVEDO, Nara; FERREIRA， Luiz Otávio; KROPF, Simone Petraglia; HAMILTON, Wanda. A profissionalização da atividade científica no IOC (1935-1960). Mimeo. Rio de Janeiro: COC/Fiocruz, 2002.

BENCHIMOL, Jaime Larry. Manguinhos do sonho à vida. A ciência na Belle Époque, Rio de Janeiro: Fundação Oswaldo Cruz/Casa de Oswaldo Cruz, 1990.

BRITTO, Nara; BENCHIMOL, Jaime Larry; HAMILTON, Wanda. Do Instituto Soroterápico Federal à Fundação Oswaldo Cruz. Fundação Oswaldo Cruz. Ciência e Saúde: a Fiocruz do Futuro. I Congresso Interno. Fase III. Suplen. p. 31-35, 1988.

BUSS, Paulo Marchiori; SHIRAIWA, Tizuko; MARANHÃO, Eduardo. Ministério de Saúde e saúde coletiva. A história de 20 anos (1953/1974). Mimeo. Rio de Janeiro: IMS/Uerj, 1976.

CAVALCANTI, Tito. Tito Cavalcanti. (depoimento, 1985). Rio de Janeiro, COC/ Fiocruz, 1985.

FONSECA, Cristina Maria Oliveira. Saúde no Governo Vargas (1930-1945: dualidade institucional de um bem público. Rio de Janeiro: Fiocruz, 2007.

HAMILTON, Wanda; FONSECA, Cristina Maria Oliveira. Política, atores e interesses no processo de mudança institucional: a criação do Ministério da Saúde em 1953. História, Ciências, Saúde - Manguinhos, vol. 10(3): 791-825, set-dez. 2003.

HAMILTON, Wanda. 'Massacre de Manguinhos': Crônica de uma morte anunciada, Cadernos da Casa de Oswaldo Cruz, No 1, V. 1, Rio de Janeiro: Casa de Oswaldo Cruz, Fiocruz, 1989.

LENT, Herman. Herman Lent. (depoimento, 1982). Rio de Janeiro: CPDOC/FVG, 1982.

LENT, Herman. O massacre de Manguinhos. Rio de Janeiro: Avenir, 1978.

MOREL, Regina Lúcia de Moraes. A política científica no Brasil, São Paulo: Queiroz, 1979.

MOTTA, Rodrigo Patto Sá. Em guarda contra o perigo vermelho: o anticomunismo no Brasil (19171964). Tese (Doutorado em História Econômica). Faculdade de Filosofia, Letras e Ciências Humanas (USP), São Paulo, 2000.

SANTOS, Daniel Guimarães Elian dos. Ciência, política e segurança nacional: o "massacre de Manguinhos" (1964-1970). Dissertação (mestrado em História das Ciências e da Saúde) da Casa de Oswaldo Cruz, Fiocruz, 2016.

SCHWARTZMAN, Simon. Um espaço para a ciência: a formação da comunidade científica no Brasil. Brasília, Ministério da Ciência e Tecnologia, Centro de Estudos Estratégicos, 2001.

SCHWARTZMAN, Simon. Ciência, universidade e ideologia. A política do conhecimento. Rio de Janeiro, Zahar, 1981.

STEPAN, Nancy. Beginnings of Brazilian Science: Oswaldo Cruz, medical research and policy, 1890-1920, New York: Science History Publications, 1976. 


\section{Posfácio}

\section{Momentos sombrios para não serem esquecidos pelas novas gerações}

Massacre de Manguinhos, obra magistral de Herman Lent - um dos mais importantes entomologistas brasileiros -, conseguiu captar a atmosfera do período da resistência que os cientistas de Manguinhos viveram durante a ditadura militar instaurada em 1964. Período de grande truculência e agressividade contra o Instituto Oswaldo Cruz (IOC), templo da ciência, célula mater da Fundação Oswaldo Cruz, a casa dos brilhantes e pioneiros Oswaldo Cruz, Carlos Chagas e Adolpho Lutz.

Ao reeditar este livro seminal da ciência brasileira, o Instituto de Comunicação e Informação Científica e Tecnológica em Saúde (Icict) e seu diretor Rodrigo Murtinho presenteiam-nos com um marco da história e da memória nacional, que não podem ser desconhecidas ou esquecidas pelas novas gerações de cientistas.

É fundamental ratificar a excelência da pesquisa desenvolvida no Instituto Oswaldo Cruz naquela época. Num significativo depoimento ao Canal Ciência do Instituto Brasileiro de Informação em Ciência e Tecnologia (Ibict), em 1983, Carlos Chagas Filho, filho de Carlos Chagas e fundador 
do Instituto de Biofísica da Universidade Federal do Rio de Janeiro (UFRJ), disse: "Eu considero um abuso muito grande a afirmação de alguns de que a glória de Manguinhos não foi mantida. O trabalho em muitos setores de Manguinhos continuou com grande produtividade até o momento em que, com o aparecimento de um mau diretor, Manguinhos teve alguns dos seus melhores elementos excluídos de seus quadros...".

Para aqueles que não viveram os anos de chumbo, faz-se relevante destacar os momentos tensos e profundamente difíceis vividos pela instituição após o golpe militar. Foram criadas comissões de inquérito e instaurados inquéritos policiais militares (IPMs) para apurar potenciais atividades subversivas, visando prejudicar e punir dez cientistas do IOC, Herman Lent, Haity Moussatché, Fernando Braga Ubatuba, Tito Arcoverde Cavalcanti Albuquerque, Hugo de Souza Lopes, Moacyr Vaz de Andrade, Augusto Cid de Mello Perissé, Sebastiao José de Oliveira, Masao Goto e Domingos Arthur Machado Filho, que tinham a excelência e a ética como cláusulas pétreas no seu trabalho institucional.

No dia $1^{\circ}$ de abril de 1970, sem que absolutamente nada fosse provado contra eles nos lamentáveis IPMs e sindicâncias, os nossos cientistas foram cassados pela ditadura militar, com base no Ato Institucional $n^{\circ}$ 5 (AI-5). Tiveram os seus direitos políticos suspensos e foram impedidos de trabalhar no IOC e em outras instituições federais. Foram momentos dramáticos para Manguinhos, para a ciência brasileira e para os seus familiares. 



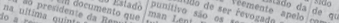

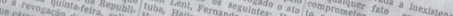

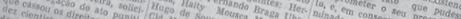

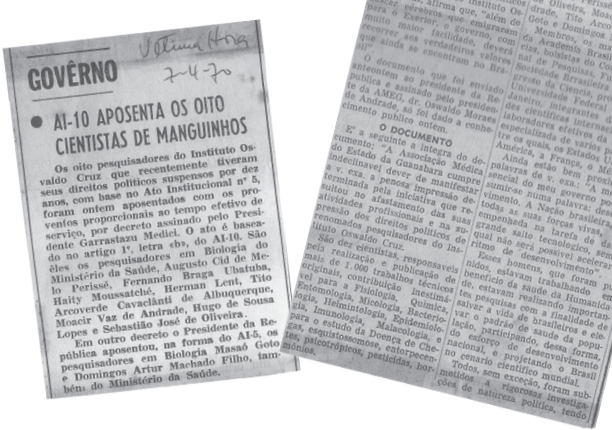

Recortes de jornais de 1970, na vigência dos

Atos Institucionais $\mathrm{n}^{\circ} 5$ e $\mathrm{n}^{\circ} 10$, que suspenderam os direitos políticos e aposentaram os pesquisadores.

As anotações nos recortes são do pesquisador Herman Lent.
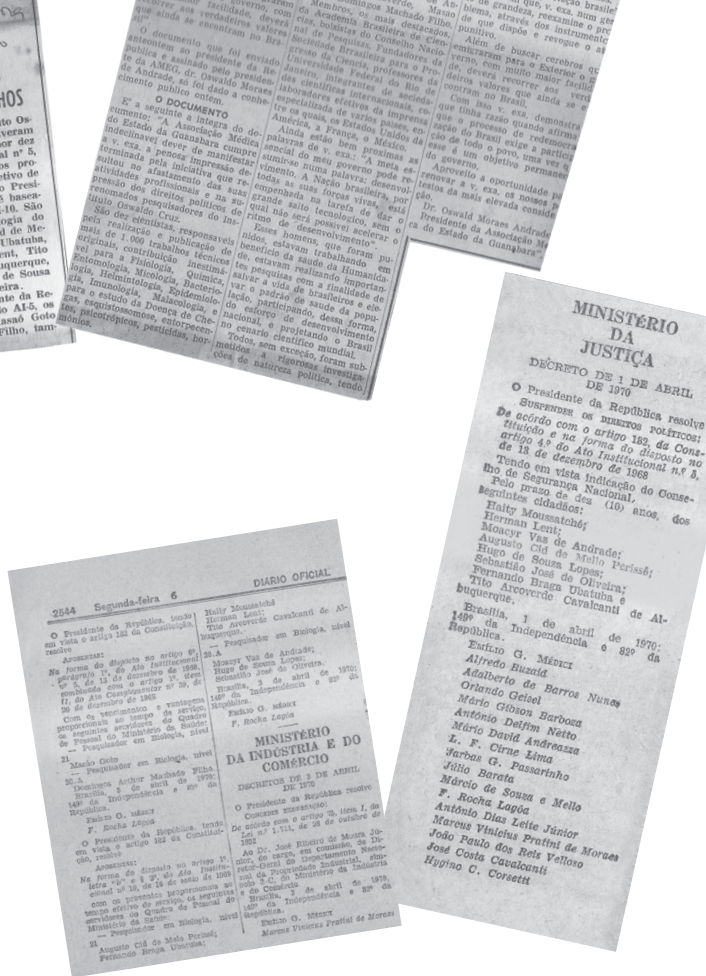
Endossando o pensamento de Carlos Chagas Filho, vale ressaltar que vários pesquisadores "subversivos" atingidos pelo AI-5 eram membros da Academia Brasileira de Ciências (ABC) e foram fundadores da Sociedade Brasileira para o Progresso da Ciência (SBPC).

Ainda hoje, é difícil acreditar que uma das ideias mais "revolucionárias" que esses cientistas defendiam era a criação do Ministério da Ciência e Tecnologia, ideia simplesmente abominada pelo diretor Rocha Lagoa.

Lamentavelmente, o primeiro a ser atingido frontalmente pela ditadura militar foi Walter Oswaldo Cruz, filho de Oswaldo Cruz, brilhante hematologista e líder de um dos laboratórios mais produtivos do Instituto Oswaldo Cruz. O seu laboratório foi lacrado e os auxílios internacionais bloqueados. Walter Oswaldo Cruz faleceu em 1967, aos 56 anos de idade, em virtude das pressões sofridas. Dois dos mais importantes bioquímicos brasileiros, Carl Peter Dietrich, da Universidade Federal de São Paulo (Unifesp), e Leopoldo de Meis, da UFRJ, foram alunos de Walter e, com toda certeza, poderiam ter permanecido no Instituto.

As pressões eram intensas, com direta interferência no dia a dia dos laboratórios. Raimundo de Britto - ministro da Saúde nomeado pela ditadura militar - afastou vários pesquisadores: “As ideias exóticas que em Manguinhos foram infiltradas serão banidas definitivamente, porque o nosso País precisa de 
Walter Oswaldo Cruz

no laboratório do IOC s.d.

Acervo Casa de Oswaldo Cruz.

$+\frac{\pi}{2} \sqrt{2}$

wimomentom

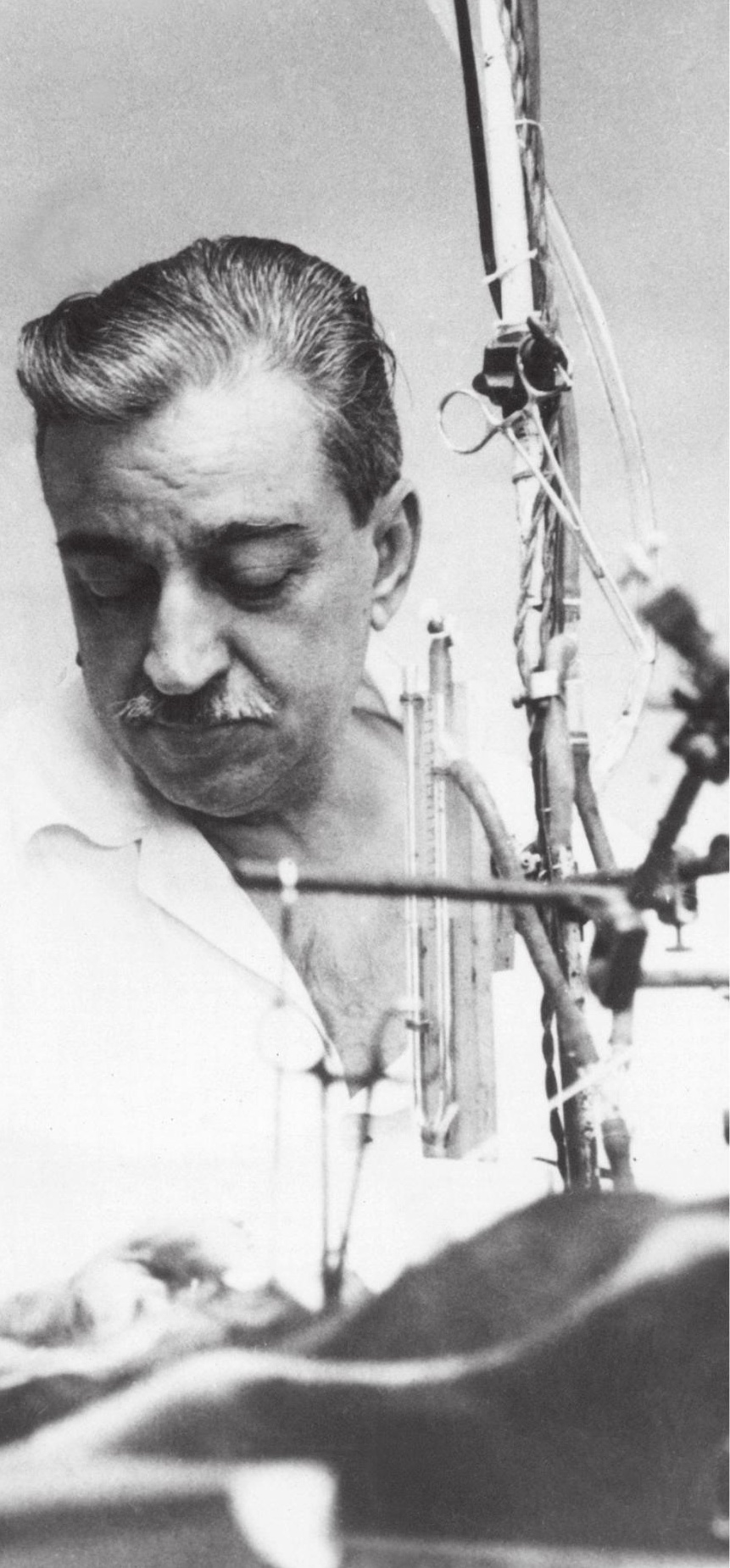

a 25

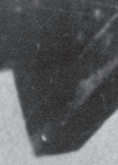

(1) 
homens que nos ajudem a acabar com o sofrimento do povo e não de elementos cujo único fito é destruir a liberdade, esfacelando o regime democrático...". Tal fala referia-se aos mais importantes cientistas brasileiros daquela época. Marcas desses anos estampam uma declaração de meu estágio com o Dr. Moussatché, carinhosamente guardada entre os meus pertences mais preciosos; nela, encontra-se carimbada a frase "A Revolução de 1964 é irreversível e consolidará a Democracia no País".

Eles se julgavam eternos...

O impacto da cassação dos dez cientistas para o corpo de pesquisadores, servidores e estudantes de Manguinhos foi dramático. Havia clara percepção de que a ditadura originaria uma era de "nuvens negras e sombrias" para o Instituto. De fato, foi uma era de grande perplexidade diante dos fatos, sobretudo, das cassações. Eu e outros estudantes, tais como Marise Jurberg, Jose Lopes Quadra, Otavio Aprigliano, Eloi Garcia - entre outros integrantes da Divisão de Fisiologia e Farmacodinâmica, criada por Miguel Ozório de Almeida -, fomos imediatamente expulsos dos laboratórios e/ou impedidos de entrar na instituição. Muitas pesquisas, sonhos e carreiras foram drasticamente interrompidos e destruídos. A cassação criou fraturas profundas nos laboratórios, projetos e cooperações nacionais/ internacionais, subitamente descontinuados. Vários pesquisadores e técnicos do IOC foram distribuídos a outras instituições do Ministério da Saúde, como os Drs. Mario Vianna Dias, Charles Esberard, Ivan 
Caldas Marins, Junia Peixoto, Maria Queiroz, Chico Trombone, entreoutros. Impactado e perplexo, o Brasil assistiu ao esfacelamento do Instituto Oswaldo Cruz, nosso templo da ciência nacional, pelo nepotismo.

Alguns pesquisadores viveram momentos de autoexilio no exterior, onde desenvolveram intensa atividade cientifica, como Haity Moussatché, na Universidad Lisandro Alvarado em Barquisimeto, Venezuela; Fernando Ubatuba, no laboratório Wellcome Research Laboratories, na Inglaterra, com John Vane (Nobel de Medicina em 1982); Herman Lent, na Universidade de Los Andes, na Venezuela, na Universidade de Assunção, no Paraguai e no Museu Americano de História Natural de Nova York; e Augusto Perissé, no Institut Max Planck,

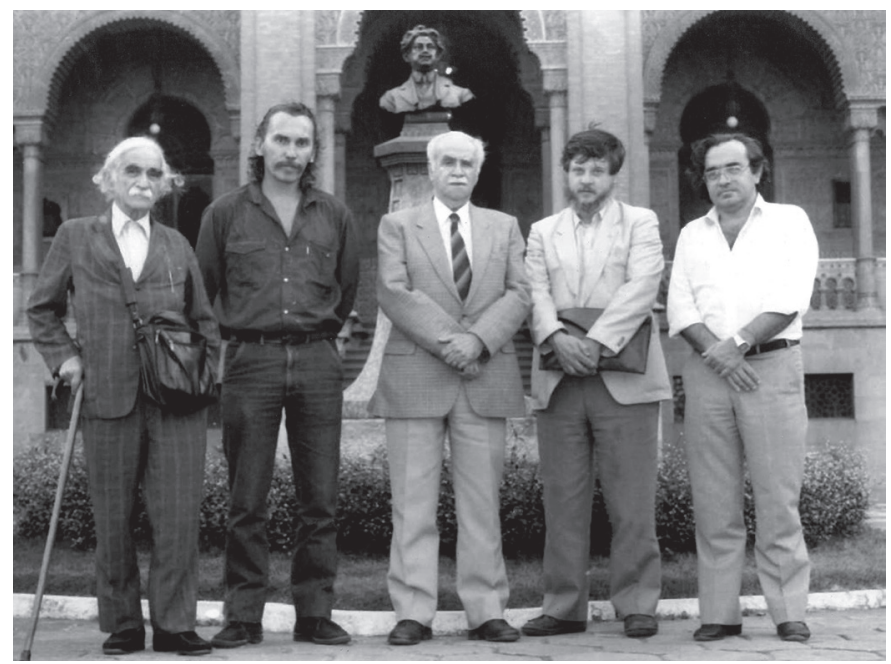

Haity Moussatché, Renato Cordeiro, Fernando Braga Ubatuba, Boris Vargaftig e Carlos Morel 1987. Acervo pessoal Renato Cordeiro | IOC. 


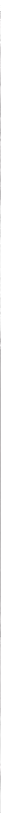

Cerimônia de reintegração dos cientistas afastados, Manguinhos, 1986.

Acervo Casa de Oswaldo Cruz. Foto: Flávio de Souza.

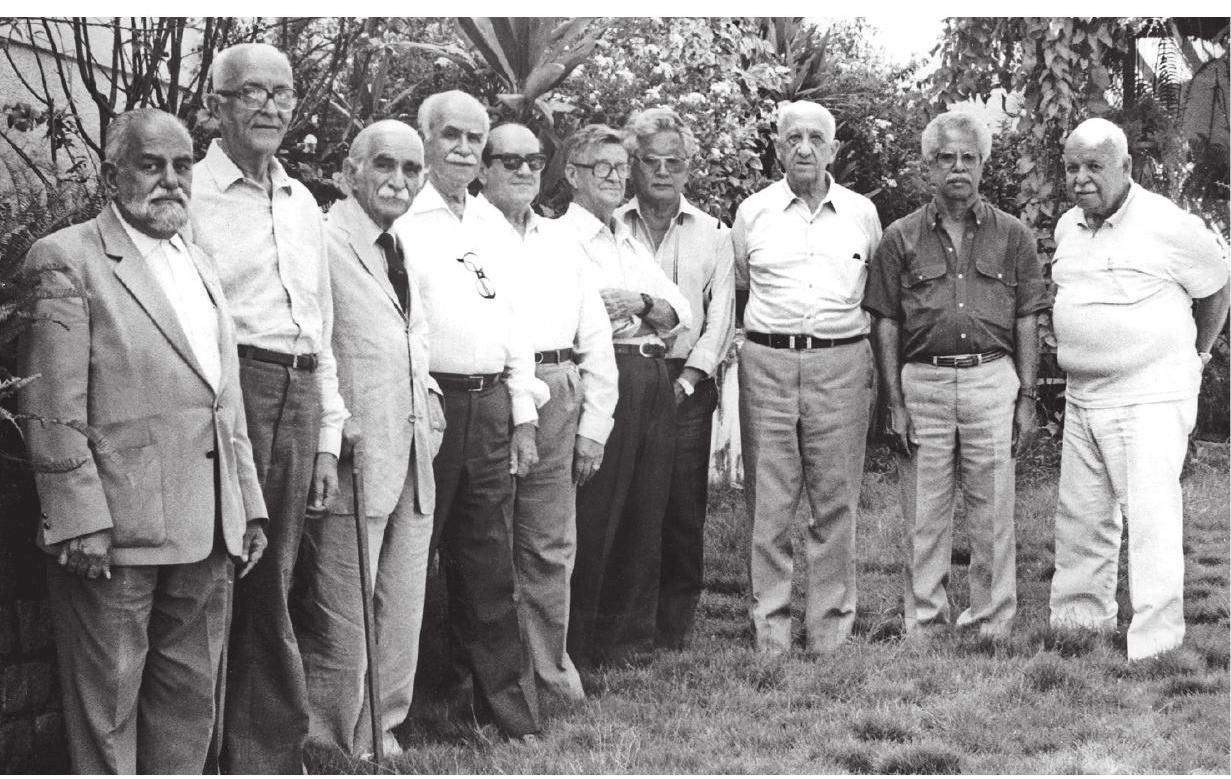

Os cassados de Manguinhos retornam à Fiocruz: (da E. para D.) Augusto Cid Mello Perissé , Tito Cavalcanti, Haity Moussatché, Fernando Braga Ubatuba, Moacyr Vaz de Andrade, Hugo de Souza Lopes, Masao Goto, Herman Lent, Sebastião José de Oliveira e Domingos Arthur Machado Filho, 1986. Acervo Casa de Oswaldo Cruz. Acervo Casa de Oswaldo Cruz. Foto: Flávio de Souza. 
em Heidelberg e na Universidade Eduardo Mondlane, em Moçambique. Vários pesquisadores que permaneceram no país exerceram atividades docentes na Universidade Santa Úrsula e em outras faculdades particulares, dada a impossibilidade de trabalharem para o governo.

Acorajosa reintegração dos cientistas de Manguinhos pelo nosso saudosíssimo Sérgio Arouca, em 1986, representou um dos mais belos e significativos gestos para a recuperação da autoestima e a oxigenação da atividade científica institucional.

A história completa do "Massacre de Manguinhos", mais um dos inúmeros episódios lastimáveis relacionados aos anos de chumbo no Brasil, ainda continuará a ser narrada... Talvez as lacunas até o momento existentes sejam preenchidas quando o conteúdo das "caixas pretas" dos ministros Francisco de Paula Rocha Lagoa (governo Médici), Raimundo de Britto (governo Castelo Branco) e dos diretores do IOC daquele período forem, finalmente, abertas pelo Arquivo Nacional, historiadores e comissões independentes. A memória daqueles anos de retrocesso científico, político e social deve ser respeitada e cultivada para que jamais retornem aos nossos dias, à história do Brasil.

Renato Cordeiro

Pesquisador Titular do Instituto Oswaldo Cruz

Pesquisador Emérito da Fiocruz Membro Titular da Academia Brasileira de Ciências

Pesquisador Senior do CNPq 
O presidente da Fiocruz Sérgio Arouca na volta do pesquisador

Haity Moussatché, 1986.

Acervo Casa de Oswaldo Cruz.

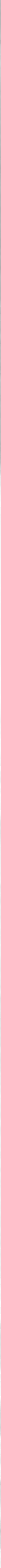




\section{BIENAL DE PESQUISA}

\section{FUNDAÇÃO OSWALDO CRUZ}

1 a 11 de dezembro de 2000

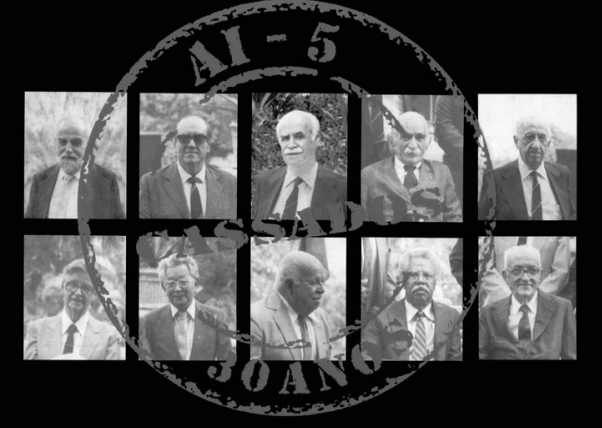

Homenagem aos cientistas do Instituto Oswaldo Cruz Cassados pelo AI-5 ( 1 de abril de 1970)

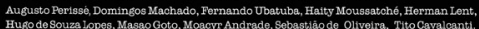

\section{"Fiocruz:}

Ciência para a Saúde

da População Brasileira."

Informaçōes:

Fundaçąo Oswalido Cruz - Vice.Presidência đe Pesquise e Ensino

Av. Brast1 4365 - Yang

Tel.: (Oxx21) 590-4712 - Fax.: (Oxx21) 590-9741

bienal@procc.flocruz.br - http://www.ficoruz.br/vppge

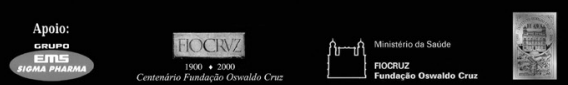

Entrega do Prêmio Fundaçáo Oswaldo Cruz

Cartaz produzido na ocasião do centenário da Fiocruz, homenageando os cientistas cassados em 1970 e que marca os 30 anos dos decretos que suspenderam os direitos políticos dos pesquisadores.

Idealização

Renato Cordeiro

Arte e projeto gráfico

Mauro Campello

Roberto Moreira 


\section{Agradecimentos}

Francisco dos Santos Lourenço Roberto Lent, João Canossa

José Paulo Leite Rodrigo Méxas

Juliana Krapp Susana Lent Santos

Maria Inês Rodriguês Taíssa Campello

Nísia Trindade Lima

Tania Santos

Paulo Elian

Vinícius Renaud

Raquel Aguiar Wanda Brant

Renato Cordeiro

Este livro foi reeditado em acesso aberto, podendo ser baixado e acessado online em tablets, smartphones, telas de computadores e em leitores de ebooks.

Este livro foi produzido pelo

Multimeios | Icict | Fiocruz

Textos compostos em Book Antiqua e Avenir Medium.

Rio de Janeiro, maio de 2019. 


\section{贵CNPq}

REALIZAÇÃO

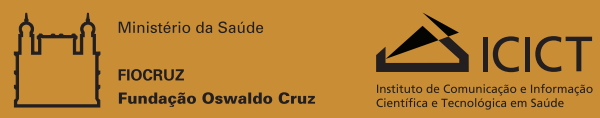

然 Casa de

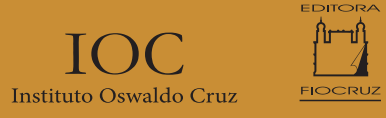

